\title{
Constitutional Improprieties: Reflections on Mistretta, Morrison, and Administrative Government
}

\author{
Stephen L. Carter $\dagger$
}

\begin{abstract}
At one of his earliest press conferences [Franklin] Roosevelt compared himself to the quarterback in a football game. The quarterback knows what the next play will be, but beyond that he cannot predict or plan too rigidly because "future plays will depend on how the next one works."'
\end{abstract}

I shall argue that under the Constitution only our politicians are entitled to the flexibility of waiting to see how one play works before calling the next one. Our constitutional courts, on the other hand-and our Supreme Court in particular-have a different role in adjudication concerning the structure of government. Notwithstanding Justice Frankfurter's famous dictum, ${ }^{2}$ the courts in structural cases should act as referees, and their proper role in determining the legitimacy of an institutional innovation is rigid enforcement of the rules. When they do less, when they defer to congressional policy judgments about the way in which federal authority is most efficiently exercised, they are acting not as courts but as participants in the legislative process.

Since the Roosevelt years the courts (and, more frequently, the commentators), in their rush to legitimate the administrative state spawned by the New Deal, have on occasion forgotten or chosen to ignore the distinction between these roles. But the distinction is important, especially when the Supreme Court performs what Charles Black has called the "legitimating func-

$\dagger$ Professor of Law, Yale University. An earlier version of this article was presented to the Law and Government Program of the University of Chicago Law School. In addition to the comments made on that occasion, I have had the benefit of more extensive critiques from Enola Aird, Bruce Ackerman, Geoffrey Miller, Roberta Romano, and Cass Sunstein. Sushma Soni provided helpful research assistance. Some of the themes in this article (and indeed, a few of the paragraphs) appeared earlier in Stephen L. Carter, Framers Lost in Sentencing Case, Legal Times of Washington 21 (Jan 30, 1989).

1 Richard Hofstadter, The American Political Tradition 327 (Alfred A. Knopf, 1973).

2 See Johnson $v$ United States, 333 US 46, 54 (1948) (Frankfurter dissenting) ("federal judges are not referees at prize fights but functionaries of justice"). 
tion"3-assuring the citizenry that their government is indeed operating in accordance with the Constitution. I shall contend that legitimating opinions that do not test new institutional forms against the original design are entitled to less deference than legitimating opinions paying closer attention to constitutional text, structure, and history. I shall further argue that two of the Supreme Court's most recent pronouncements on the constitutionality of the exercise of federal power through independent entities, Morrison v Olson ${ }^{4}$ and Mistretta $v$ United States, ${ }^{5}$ unfortunately suffer from precisely this defect.

Finally, I shall agree with those theorists who suggest that the duty of legislators to make independent constitutional assessments never ceases; but I shall note in particular the possibility-indeed the likelihood-that there will be occasions on which the Supreme Court, rightly or wrongly, will hold a particular action to be within the power of the federal government, and yet a legislator will be left with the sense that the action is contrary to the spirit of the Constitution. Such actions I refer to as constitutional improprieties, and I shall argue that even when the Court has ruled an act constitutionally valid, it may nevertheless be constitutionally improper. In the continuing constitutional conversation among the Court and its various constituencies, a refusal to act on the ground of constitutional impropriety is an appropriate and potentially important tool for dialogic interchange.

The fundamental rights arena is readily mined for examples. What is easily overlooked, however, is that structural constitutional law also leaves room for constitutional improprieties-and constitutional dialogue. The Court's opinions in Mistretta and Morrison may seem to legitimate certain aspects of administrative governance, but because the Justices have not yet met the strongest arguments the other way, a sensitive legislator might yet decide to consider the agencies constitutionally improper. And constitutionally improper legislation is as much to be avoided as legislation that is plainly unconstitutional.

\section{Morrison, Mistretta, AND the Administrative Constitution}

In recent years, commentators by the host have challenged the constitutional authority of the federal government to vest legisla-

\footnotetext{
${ }^{3}$ Charles L. Black Jr., The People and the Court 56-86 (Prentice-Hall, 1960).

- 108 S Ct 2597 (1988).

${ }^{5} 109 \mathrm{~S} \mathrm{Ct} 647$ (1989).
} 
tive or executive powers in agencies that are formally independent of legislative or executive control. ${ }^{6}$ According to these critics, the rise of what has come to be called the administrative state is inconsistent with the separation of powers. Back at the dawn of the New Deal, one corner of this position, the non-delegation doctrine, was even pronounced as constitutional law. ${ }^{7}$ But the Supreme Court that enunciated the doctrine, battered by political criticism and perhaps sensitive to the needs of the nation, finally backed down. ${ }^{8}$

Until recently, the New Deal cases were thought to have settled the matter. Evidently, they did not. Unconcerned that the Supreme Court ignores their views, the current critics have pressed the many variations of the separation of powers argument with mounting enthusiasm-and mounting success. Over the past decade and a half the Supreme Court has seemed quite hospitable to arguments that particular institutional arrangements are unconstitutional because they run afoul of the Founders' design for the operation of the federal government. Separation of powers, as a judicially enforceable doctrine, seemed to be in the midst of a comeback as dazzling as it was unexpected.

Just a few years ago, then, fans of this well-worn but durable doctrine were celebrating a Supreme Court that at last seemed ready to force a return to federal governance on the model developed by the Founders. The Congress, which for years had been establishing new institutions and agencies of governance without serious judicial challenge, was rocked back on its heels when the Justices struck down in quick succession the legislative veto and the original Gramm-Rudman-Hollings budget law, holding that both violated the original understanding on the separation of powers. ${ }^{9}$ In those and other cases, the Court admonished sternly that

- See, for example, Harold H. Bruff, Presidential Power and Administrative Rulemaking, 88 Yale L J 451 (1979); Geoffrey P. Miller, Independent Agencies, $1986 \mathrm{~S} \mathrm{Ct} \mathrm{Rev} \mathrm{41;}$ and Stephen L. Carter, The Independent Counsel Mess, 102 Harv L Rev 105 (1988).

${ }^{7}$ See A.L.A. Schechter Poultry Corp. $v$ United States, 295 US 495 (1935); and Panama Refining Co. $v$ Ryan, 293 US 388 (1935).

"The supposed "switch in time" that "saved nine" was NLRB $v$ Jones \& Laughlin Steel Corp., 301 US I (1937), which gave President Roosevelt the broad reading of congressional commerce power that he wanted. The non-delegation doctrine was formally buried seven years later in Yakus $v$ United States, 321 US 414 (1944). For a discussion of the "court-packing" plan that represented President Roosevelt's effort to force the Justices off the sidelines and into the game, see Robert H. Jackson, The Struggle for Judicial Supremacy 187-235 (Random House, 1941). For a short and useful analysis of the jurisprudential changes wrought by the "switch in time," see Archibald Cox, Hughes Court (19301941), in Leonard W. Levy, Kenneth L. Karst, and Dennis J. Mahoney, eds, 2 Encyclopedia of the American Constitution 933, 934-38 (MacMillan, 1986).

- See INS v Chadha, 462 US 919 (1983); and Bowsher v Synar, 478 US 714 (1986). 
considerations of policy and efficiency, even of pressing public necessity, are not sufficient justifications for altering the original scheme.

For example, in INS $v$ Chadha ${ }^{10}$ the Justices ruled that the Congress lacked the power to delegate authority' while retaining a legislative veto over its exercise. Faced with the argument that administrative government would work more efficiently if the power were recognized, the Justices issued a sharply originalist rebuff: "[I]t is crystal clear ... that the Framers ranked other values higher than efficiency." Similar language regarding the obligation of the federal government to act in accord with the Founders' institutional design appears in other recent decisions. ${ }^{12}$ It seemed for a time that after decades of dithering, the Justices at last had adopted (albeit narrowly) a consistent approach to separation of powers cases. To be sure, the chosen approach was severely criticized as over-zealously originalist and formalistic, ${ }^{13}$ but the Court's defenders responded that a bit of originalism in structural cases was a good thing. ${ }^{14}$

Then, two terms ago, things changed. In Morrison $v$ Olson, ${ }^{15}$ the Court sustained, by a vote of 7 to 1 , the law providing for the appointment of independent counsels to investigate and prosecute allegations of wrongdoing in the executive branch. The surprise was not the result, but the Court's reasoning. The painstaking assessment of the original understanding (sometimes described, mistakenly in my view, as a "strict" separation of powers) that had

10462 US 919 (1983).

11 Id at 958-59.

12 See, for example, Bowsher, 478 US at 722 (government must heed original design even when doing so "produces conflicts, confusion, and discordance"); Northern Pipeline Construction Co. v Marathon Pipe Line Co., 458 US 50, 73 (1982) (plurality opinion) (Congress cannot ignore original design "whenever it finds that course expedient"); and Buckley $v$ Valeo, 424 US 1, 134 (1976) (per curiam) (concerns about effectiveness "do not by themselves warrant a distortion of the Framers' work").

${ }^{13}$ See, for example, E. Donald Elliott, Why Our Separation of Powers Jurisprudence Is So Abysmal, 57 Geo Wash L Rev 506, 515-18 (1989); Paul Gewirtz, Realism in Separation of Powers Thinking, $30 \mathrm{Wm}$ \& Mary L Rev 343, 343 (1989); Philip B. Kurland, The Rise and Fall of the "Doctrine" of Separation of Powers, 85 Mich L Rev 592, 592-93, 605-13 (1986); Peter L. Strauss, Formal and Functional Approaches to Separation-of-Powers Questions-A Foolish Inconsistency?, 72 Cornell L Rev 488, 496-502 (1987); and Cass R. Sunstein, Constitutionalism After the New Deal, 101 Harv L Rev 421, 493-96 (1987).

14 See, for example, Stephen L. Carter, From Sick Chicken to Synar: The Evolution and Subsequent De-Evolution of the Separation of Powers, 1987 BYU L Rev 719, 778-800; Harold J. Krent, Separating the Strands in Separation of Powers Controversies, 74 Va L Rev 1253, 1261-72 (1988); and Miller, Independent Agencies, 1986 S Ct Rev at 52-58 (cited in note 6 ).

1s $108 \mathrm{~S} \mathrm{Ct} 2597$ (1988). 
dominated separation of powers jurisprudence in recent years was conspicuous by its absence. The Justices instead deferred to the congressional judgment that independence was necessary to facilitate investigation and prosecution of executive miscreants.

Next, in the middle of the 1988-89 term, the notion that separation of powers disputes should be governed by close attention to the text, structure, and history of the Constitution received perhaps its most stunning setback. In Mistretta $v$ United States ${ }^{16}$ the Supreme Court (over a blistering dissent from Justice Scalia) held that the Congress may constitute an independent agency and grant it the authority to bind federal judges to the sentencing ranges that the agency considers appropriate for various offenses.

As Erwin Chemerinsky has pointed out, the majority opinion in Mistretta "is internally inconsistent in its use of constitutional history," relying on a bit of history (although less than Chemerinsky implies) in resolving the separation of powers question, but none at all on the question of delegation of legislative authority-the more difficult of the two. ${ }^{17}$ But the methodology is only part of the problem. The implications of Mistretta are also troubling, for if the Congress may create an agency with the powers of the Sentencing Commission, it is hard to envision one that would be forbidden.

Taken together, Mistretta and Morrison should have rudely awakened observers of the Supreme Court whom the tantalizingly consistent run of recent decisions had lulled into supposing that the Justices had finally sorted out the separation of powers. For Mistretta, if it did nothing else, certainly proved that Morrison was no fluke. ${ }^{18}$ In both cases, the congressional policy judgment was what mattered most. in neither case did the Court deem it necessary to undertake an extensive investigation of the views of the Founders on the separation of powers. And, in both cases, the establishment of an agency beyond the direct control of any

\footnotetext{
$109 \mathrm{~S} \mathrm{Ct} 647$ (1989).

${ }^{17}$ Erwin Chemerinsky, The Supreme Court, 1988 Term-Foreword: The Vanishing Constitution, 103 Harv L Rev 43, 53 (1989). Chemerinsky adds that because "the delegation issue was considered at the Constitutional Convention," the reader "is left with the impression that the Court is originalist only when it justifies the result that the Court wants." Id. For reasons I will make clear below, the form of originalism that I prescribe pays little attention to Madison's notes on the convention. My interest in ratification and popular debate rather than the confidential deliberations on drafting and creation is the principal reason for my reference to the "Founders" rather than the "Framers."

${ }^{18}$ Chemerinsky is of the view that the Rehnquist Court's judicial philosophy is largely one of deference to the majoritarian branches, see id at 56-59, 74-97, which would help explain the methodology of Morrison and Mistretta.
} 
branch specified in the Constitution received a ringing endorsement from the Court.

So, while the vision of a judicially-enforced separation of powers may not quite be down for the count, it is certainly sagging on the ropes. To be sure, administrative government was already wellestablished when Morrison and Mistretta came along. One may trace its development all the way back to the "Decision of 1789," and the rich and lively congressional debate on removal of the Treasury Secretary which involved, among other things, the question whether the public funds ought to be placed into the hands of an individual or agency beyond political control. ${ }^{19} \mathrm{Or}$, if one prefers to seek judicial provenance, one need look no further than $M c$ Culloch $v$ Maryland, ${ }^{20}$ the case in which Chief Justice Marshall, in ringing and decisive terms, destroyed forever the myth that the federal government's powers under Article I, Section 8, were restricted rather than enhanced by the writtenness of the Constitution.

In practical terms, however, judicial approval of modern administrative government began in 1935, when the Supreme Court decided in Humphrey's Executor v United States ${ }^{21}$ that the Congress may create agencies beyond the direction of either the executive or legislative branches and grant to those agencies the authority to act "in part quasi-legislatively and in part quasi-judicially." 22 As scores of critics have pointed out in the ensuing fifty-five years, the Court in Humphrey's Executor neglected to explain precisely

191 Annals of Congress 400-12, 616-32, 636-40 (1789). What has come to be called the Decision of 1789 was the outcome of a heated debate in the First Congress over whether the Treasury Department should be under legislative rather than executive control. See Edward S. Corwin, The President: Office and Powers 86-89 (NYU, 4th ed 1957); and Joseph P. Harris, The Advice and Consent of the Senate 30-33 (U Cal, 1953). Louis Fisher has gone so far as to argue that the actual decision was ambiguous, and that in the early years of the republic, the Treasury might have enjoyed a special status. See Louis Fisher, President and Congress: Power and Policy 86-89 (Free Press, 1972). One must be cautious, however, about making too much of the Decision of 1789 . The deliberations of the First Congress are not necessarily reliable guides to a shared original understanding, because even the drafters and ratifiers were practical politicians, as willing as anyone else to twist and distort the new Constitution in pursuit of a political end. Besides, the ultimate decision went in the other direction; that is, against independence for the Treasury. But even had the First Congress clearly established an independent Treasury, the Treasury might in any case hold a special constitutional status: It is the only department explicitly mentioned in the Constitution. See US Const, Art I, $\$ 9, \mathrm{cl} 7$. For an overview of the rise of administrative government during the past century, see Robert L. Rabin, Federal Regulation in Historical Perspective, 38 Stan L Rev 1189 (1986).

2017 US 316 (1819).

21295 US 602 (1935).

22 Id at 628 . 
what aspect of the Constitution granted the power to create independent entities of this kind. ${ }^{23}$ Nor have the Justices troubled to do so in any subsequent opinion. Moreover, Humphrey's Executor at least limited and might have overruled Myers v United States, ${ }^{24}$ the only decision in which the Justices actually sifted through the views of the Founders on the ability of the Congress to establish entities exercising executive authority but independent of executive control. ${ }^{25}$

Nevertheless, most constitutional scholars, and nearly all courts, treat the matter as settled law. In a positivist sense it certainly is, for the highest court in the land shows every sign of satisfaction with a doctrine that permits the Congress and the President to experiment with institutional forms never contemplated by the Founders and possibly quite foreign to their political science. The difficulty is that while we have a positivist answer to the question of constitutionality, we have no authoritative assessment of the historical evidence.

So although one might be tempted to say in the wake of Morrison, and even more so in the wake of Mistretta, that the constitutional status of the administrative state is no longer in question, that is too broad and unthinkingly positivist a construction of the relationship between law and interpretation. Better, surely, to spend a moment as a legal realist, and to say simply that it seems unlikely that the Supreme Court will at any time in the near future strike down as unconstitutional any of the major aspects of the administrative state-in particular, the assignment of legislative or executive authority to agencies beyond direct political supervision. That conclusion tells what the law is, in the sense of what the Supreme Court has said; it does not tell what the law ought to be, and it does not say anything at all about "constitutional status."

This distinction matters. Strong arguments are still available that independent agencies have the status of constitutional outlaws, something contrary to the evident constitutional plan. To say that strong arguments are available is not to say that the arguments must convince, and there are of course clever arguments the other way. By tradition, we look to the Supreme Court to resolve these conflicts. But in our relentlessly positivist public debate, we

${ }^{23}$ See, for example, Carter, 102 Harv L Rev at 128 (cited in note 6).

24272 US 52 (1926).

${ }^{25}$ On whether Myers has been overruled sub silentio, see Carter, 102 Harv L Rev at 129-34 (cited in note 6). 
all too often act as though what matters most is the Court's interpretive authority; once the Court has announced a constitutional interpretation, the matter is considered settled. ${ }^{26}$

But the Court also serves a dialogic function: it answers questions, and sometimes puts questions of its own. The difficulty with the Supreme Court's recent opinions on the independence of government entities (and the difficulty with the old opinions, too) is that they simply do not answer most of the questions raised by skeptics of agency independence. When the Supreme Court fails to engage in dialogue, its view prevails (if at all) only because of our tradition of finality, not because the Justices have convinced their critics. In Morrison and Mistretta, they haven't even tried.

\section{The De-Evolutionary Tradition}

The study of separation of powers, moribund through most of the rights-happy seventies, has recently undergone a resurgence. The flowering of the separation of powers cases ought to be unsurprising in our era of divided government, with the executive and legislative powers consistently in the hands of different political parties. With the President and the Congress more likely to do battle, and with our peculiar habit of settling political differences through litigation, separation of powers cases are sure to arise more often than they once did. Besides, the rising generation of scholars seems to harbor an ingrained mistrust of concentrated power, much as the Founders did, and therefore may be seeking a richer understanding of the manner in which the awesome might of the federal government can be reined in. Whatever the reason, attention to what might be called the Political Constitution-the clauses establishing the structure and function of the federal government-has grown increasingly popular. ${ }^{27}$

The Supreme Court, perhaps unsurprisingly, has shown little interest in the fascinating (and occasionally strident) academic debate over the best approach to adjudication under those clauses. On the contrary, separation of powers cases too often seem to be decided on the basis of either a cramped originalism that assumes (1982).

${ }^{26}$ Compare Owen M. Fiss, Objectivity and Interpretation, 34 Stan L Rev 739, 755-58

${ }^{27}$ I introduced my concept of the Political Constitution in Stephen L. Carter, Constitutional Adjudication and the Indeterminate Text: A Preliminary Defense of an Imperfect Muddle, 94 Yale L J 821, 847-70 (1985). See also Carter, 1987 BYU L Rev at 778-800 (cited in note 14); and Stephen L. Carter, The Right Questions in the Creation of Constitutional Meaning, 66 BU L Rev 71, 72-81 (1986). 
that a glance at the sacred text of Madison's notes will resolve all questions, or a policy analysis that could have been written by a congressional staffer.

This failure of the Court to produce a coherent theory is particularly ironic when placed alongside the reasonably consistent doctrines and workable tests that the Justices have developed to govern adjudication under such open-ended provisions as the First, Fifth, and Fourteenth Amendments. True, the doctrines have been challenged and their application to particular cases questioned, but for those who believe in judicial process, the simple fact of taking the Constitution seriously-which, in my view, the entire Court struggles to do when individual rights are at issue-is reassuring. When facing structural problems in general, however, and separation of powers questions in particular, the Justices sometimes seem to consider the possibility of constitutionalism almost as an afterthought.

This approach might have matters exactly backward. Perhaps constitutionalism is more important in structural cases than in cases about rights. Perhaps it is important to have clear, determinate answers about the structure of government so that those who want to change the way the world works understand where the power lies. What might be needed is a constitutional "safe harbor," a part of constitutional governance that is shielded from the winds of change that blow constantly through society. ${ }^{28} \mathrm{~A}$ judiciary that draws its authority from the construction of a relatively determinate interpretation of the structural provisions of Article III and Article VI could do much worse than insist on similarly determinate guidance for the other branches of the federal government. If all provisions of the Constitution are equally fluid, if relatively determinate results are no more possible in reading the Presentment Clause than in reading the Equal Protection Clause, then all of governance is essentially left up for grabs, and it becomes difficult to defend the claim that constitutionalism limits in any coherent sense the structure and operations of the government of the United States. In the words of Richard Epstein, "The importance of a fixed constitutional framework and stable institutional arrangements is necessarily lost once the framework that was designed to place a limit upon politics becomes the central subject of the politics it was designed to limit." ${ }^{2 \theta}$ If the structural provi-

${ }^{28}$ See Carter, 94 Yale L J at 864-65 (cited in note 27).

${ }^{29}$ Richard Epstein, Toward a Revitalization of the Contract Clause, $51 \mathrm{U}$ Chi L Rev 703,736 (1984). In borrowing Epstein's useful language to describe a problem under the 
sions of the Constitution evolve freely as the felt political needs of the country change, then we might as well say that the federal government controls the Constitution rather than, as we teach schoolchildren, the other way around.

Something like this, I think, is what Joseph Raz had in mind when he wrote in The Morality of Freedom:

Federal states distinguish between ordinary political action, which takes place within the existing framework of political institutions, and political action which changes that very framework. They tend to endorse special procedures for the second, procedures which have a built-in conservative bias in them, that is a bias which make[s] constitutional changes more difficult to effect than ordinary political action. ${ }^{30}$

The entire point of a constitution that governs structure is to enable government to function while restraining the ability of government to restructure itself. I have elsewhere referred to the effort to use the vision of the Founders to effect that restraint in separation of powers cases as the de-evolutionary tradition. ${ }^{31}$

Legend has it that the great chess genius Rudolf Spielmann was once asked why he always opened his games with the same move. Spielmann replied, "Because I never make a mistake in the opening!" This was of course an exaggeration; Spielmann did not always open with the same move, and when he did, he did not always win. But he usually opened with the same move, and he usually won. In any event, the philosophy underlying his answer ought to intrigue constitutional theorists. Spielmann was insisting, in a positive rather than normative sense, that there is a single best move in every position that might occur on the board, including the opening position with the thirty-two pieces resting on their initial squares.

Similarly, I would argue (but now in a normative sense) that there is a single best interpretive move when a court is called upon to apply the structural clauses of the Political Constitution. The Political Constitution, after all, is different from what might be called the Natural Law Constitution, in which the rights of indi-

\footnotetext{
Political Constitution, I should not be read as necessarily endorsing his analysis of the Contracts Clause of Article I, which, in his view, the Supreme Court disregarded in Home Bldg \& Loan Ass'n $v$ Blaisdell, 290 US 398 (1934). Id at 735-38.

${ }^{30}$ Joseph Raz, The Morality of Freedom 259 (Clarendon, 1986).

32 See generally Carter, 1987 BYU L Rev 719 (cited in note 14).
} 
viduals are set forth. ${ }^{32}$ Peter Strauss has written that "[o]ne scanning the Constitution for a sense of the overall structure of the federal government is immediately struck by its silences," fear that he has matters backward. The 1787 Constitution reflects the enormous energy that the Founders expended on designing the structure of the federal government; in the words of John Ely, "the original Constitution was principally, indeed I would say overwhelmingly, dedicated to concerns of process and structure." ${ }^{134}$ The Political Constitution consists of relatively determinate clauses phrased by their authors with highly specific referents in mind. The clause requiring that the President be thirty-five years of age, for example, while not, perhaps, utterly unambiguous, ${ }^{35}$ hardly poses the same interpretive difficulties as the Equal Protection Clause. As Frederick Schauer has noted, moreover, the American government functions within these structural clauses without the need for constant resort to judicial interpretation; people seem to agree on what most of them mean..$^{36}$ Or rather, as my junior high school English teacher used to say, people seem to agree on how they mean: they mean what the Founders thought they meant.

The obvious response to this proposition is to dismiss it, even if accurate, as irrelevant: Why should a constitutional interpreter care what (or how) the American public believes the structural clauses of the Political Constitution mean? The answer is that the authoritative constitutional interpreter-the interpreter who claims the power to frustrate the combined will of a majority of the people's legislative representatives and the elected chief executive-should care because an interpretation that disregards this popular constitutional hermeneutic expectation lacks legitimacy in a liberal democratic polity. And the interpreter who does care about the constitutional vision of the demos, the Court's public,

${ }^{32}$ My choice of terminology is influenced in part by Suzanna Sherry's provocative article, The Founders' Unwritten Constitution, 54 U Chi L Rev 1127 (1987).

${ }^{33}$ Peter L. Strauss, The Place of Agencies in Government: Separation of Powers and the Fourth Branch, 84 Colum L Rev 573, 597.

"John Hart Ely, Democracy and Distrust 92 (Harvard, 1980). See also H. Jefferson Powell, How Does the Constitution Structure Government?, in Burke Marshall, ed, A Workable Government: The Constitution After 200 Years 13 (W.W. Norton, 1987). Although my discussion here is only of the system of checks and balances within the federal government, I recognize that the Founders designed checks to run vertically as well as horizontally. For a provocative assessment of the original vision of the roles of the state and federal sovereignties in checking one another, see Akhil Reed Amar, Of Sovereignty and Federalism, 96 Yale L J 1425 (1987).

${ }^{35}$ See Mark V. Tushnet, $A$ Note on the Revival of Textualism in Constitutional Theory, $58 \mathrm{~S}$ Cal L Rev 683, 686-87 (1985).

3s See Frederick Schauer, Easy Cases, 58 S Cal L Rev 399, 408-14 (1985). 
should choose to adjudicate cases under the structural provisions of the Political Constitution in accord with the de-evolutionary tradition.

I understand that my assertion is a controversial one, but this is not the place for a lengthy elucidation of the reasons for my conclusion that only de-evolutionary review can carry legitimating force; ${ }^{37}$ for the curious reader, I cite the relevant sources in the margin..$^{38}$ It might, however, be appropriate to recapitulate the argument here, albeit briefly and obliquely.

I begin with the proposition that much of the narrative significance of American constitutionalism flows from a mythos that venerates the Founders and assumes that our governmental institutions are contiguous with theirs, that we are in effect operating in accordance with the rules they laid down. ${ }^{39}$ Nothing in the argument turns on the truth of this assumption. Judges and constitutional theorists know, or think they do, that the mythos is false: that the governance of the late twentieth century post-industrial American state bears little resemblance to the agrarian "democracy" that the Founders envisioned. But the irrelevance of the Founders' political science to our era is a proposition to be argued, not assumed; and even should the wisdom of the Founders turn out to be nonsense when translated to our era, the question of who should hold the power to abandon it sits uneasily and unanswered

${ }^{37}$ Erwin Chemerinsky, who has done me the complement of writing a very thoughtful response to my views, see Wrong Questions Get Wrong Answers: An Analysis of Professor Carter's Approach to Judicial Review, 66 BU L Rev 47 (1986), and has subsequently incorporated some of the same material in a fine book, see Interpreting the Constitution 77-80 (Praeger, 1987), has listed and rebutted what he says are the three reasons why I support "originalism" in structural adjudication. Quite apart from the fact that I am not sure that the unmodified word "originalism" captures the form of review that I have in mind, I fear that none of the three reasons that Professor Chemerinsky cites are the reasons I advocate the approach I do. (If anything in my earlier work has given the wrong impression, such was not my intention).

38 The justification for de-evolution, although I had not yet hit upon the name, was first set out in Carter, 94 Yale $\mathrm{L} J$ at 853-70 (cited in note 27). A more formal presentation appears in Carter, 1987 BYU L Rev at 778-800 (cited in note 14). A somewhat sharper and more refined vision is sketched in Carter, 102 Harv $\mathrm{L}$ Rev at 118-28 (cited in note 6).

${ }^{39}$ My colleague Paul Kahn calls this the myth of intertemporal identity. Paul W. Kahn, Reason and Will in the Origins of American Constitutionalism, 98 Yale L J 449, 508 (1989). I recognize, of course, certain obvious parallels between a form of originalism that glorifies the Philadelphia event and ancestor-worship. See Carter, 1987 BYU L Rev at 738-39 (cited in note 15). But I emphatically do not base my advocacy of de-evolutionary review on any form of veneration of the Founders. The Founders, by and large, supported or tolerated chattel slavery, the oppression of women, and the exclusion of the poor from the franchise. For more on this, see Stephen L. Carter, The Role of the Courts in Seperation of Powers Disputes, - Wash U L Q - (forthcoming, 1990). 
on the interpreter's shoulder. For whatever smart theorists may know, the people may yet believe that the continuity exists, and may even place their allegiance-let us say, their consent-on that ground.

Perhaps, as critics often charge, the American political system really contains no functional equivalent of the consent of the governed, whether actual or tacit. But if political obligation is willed at all, it is surely willed against the background of the role that our myths about the Founding play in popular attitudes about American Government. The Founders, in American political iconography, are the larger-than-life figures who met at Philadelphia at the dawn of the nation's history and joined in the most successful act of constitutional creation the world has ever known. ${ }^{40}$ As Sanford Levinson has pointed out, the Philadelphia Convention "is most certainly, and profoundly, an event in addition to a text."41 Whether treated as text or event, says Levinson, "'Philadelphia' itself gains meaning only from being placed within a narrative structure, itself of civil religious dimension." 42

On this point, it is appropriate to consider Raz once more: "[O]ne may distinguish in every country between the basic political culture of that country, and its more detailed and transient arrangements." ${ }^{\text {43 }}$ The basic political culture of the United States, I would argue, rests in large measure on both the Philadelphia event and the idea that we are governed in accordance with the framework that it spawned. ${ }^{44}$ The basic culture excludes particular political initiatives. The distinction, as Raz says, "is one of degree, and is not susceptible to precise description." ${ }^{25}$ But the distinction is there, and contemporary theorists often miss it. For example, Bruce Ackerman in his Storrs Lectures suggests that the American people, in the crucial constitutional moment of the 1936 elections, essentially amended the Constitution to strike the Philadelphia structure and replace it with the structure of the New Deal. ${ }^{46}$ Pos-

10 Much of this argument is paraphrased from Carter, 102 Harv L Rev at 120 (cited in note 6). See also Frank Michelman, Law's Republic, 97 Yale L J 1493, 1515-18 (1988).

1S Sanford Levinson, Constitutional Faith 134 (Princeton, 1988).

12 Id.

43 Raz, Morality of Freedom at 259 (cited in note 30).

11 In addition to Sanford Levinson's book cited in note 41, a good account of the continuing significance of the Philadelphia event in American political iconography is Michael Kammen, A Machine That Would Go of Itself: The Constitution in American Culture (Knopf, 1986).

is Raz, Morality of Freedom at 259 (cited in note 30).

* Bruce A. Ackerman, The Storrs Lectures: Discovering the Constitution, 93 Yale L J 1013, 1054-57 (1984). Ackerman considers the constitutional document a representation, 
sibly so-but I am not at all sure that the public veneration of the founding of modern administrative government matches the awe that attaches to Philadelphia as an event.

Still, Ackerman is right to focus his analytical attention on The People-the demos. Because even if the public has no idea what is in the Constitution, the people evidently believe that the American government, the Republic to which schoolchildren daily pledge allegiance, is in its basic structure the one that the Foun-

built up by semiosis (mimesis is obviously not possible) to signify the underlying constitutional politics that led to its creation. But, he argues, precisely because of the document's semiotic character, it is the fundamental choices that the Constitution signifies, and not the document itself, that are entitled to binding authority. His central claim is that since it is the resolution of a struggle of constitutional magnitude that carries binding force, the constitutional interpreter ought to be indifferent as to whether the resolution is signified in a document or in some other form. In Ackerman's view, for example, the 1936 elections signify the resolution of a constitutional struggle over the breadth (and perhaps the structure) of government regulatory authority, a political moment of constitutive dimensions, and one that the interpreter should not trivialize or ignore simply because it is not signified by a document.

The constitutional document, then, is an artifact, an essentially arbitrary choice among possible signs to signify the underlying understanding. By reasoning in this fashion, Ackerman might seem to be following a basic rule of semiology, nicely put by Robert Scholes: "[I]n all (or nearly all) signs the sound-image is in no way dictated by the concept." Robert Scholes, Structuralism in Literature: An Introduction 15 (Yale, 1974). See also Umberto Eco, $A$ Theory of Semiotics (Indiana U, 1976). Indeed, Ackerman's approach might seem on its face to meld the political theoretic ideal of popular consent with the linguistic and psychological evidence that people remember meaning (the signified, the constitutional understanding) with far greater accuracy than they remember the text (the signifier, the constitutional document). See E.D. Hirsch, The Philosophy of Composition 122-29 (U Chicago, 1977) (summarizing research).

The trouble is that the arbitrariness of the sign does not necessarily imply the irrelevance of the sign. To quote Scholes once more:

The connection between sound and concept is arbitrary with respect to nature, of course, but not to culture. We who grow up in English must call a tree a tree if we wish to be understood. It is possible to be offended by this state of affairs, to see in it an existential absurdity, but this would be an un-Saussurean and unstructuralistic response. The arbitrariness of the sign in no way need imply the arbitrariness of the concept or its adequacy as an image of reality.

Scholes, Structuralism in Literature at 16 . This, indeed, is the point of semiology: placed within their cultural context, the signs do matter. One sign is not just as good as another, simply because both are used to signify the same concept. So even if Ackerman is correct (which I do not concede) in insisting that the level of constitutional politics during the New Deal was comparable to the level of constitutional politics during the Founding, nothing about the universe of acceptable signs follows therefrom. Especially when one is concerned with the consent of real people to a real government structure, one wants to know the symbols--the signs-that matter to them. The American public has always had a special reverence for the Founders and the Founding, and the Constitution is a symbol of our continuity with the Founding Generation. See Kammen, A Machine That Would Go Of Itself (cited in note 44). Ackerman's argument works only if as a matter of American popular political iconography, the New Deal as a symbol of permanent structural change rivals the Founding as a symbol of the same thing, an assertion distantly plausible but on the whole unpersuasive. 
ders designed. It should matter little to the interpreter whether the people are right or wrong in assuming that the structure of our government has been handed on by past generations substantially continuous with our own; it should matter still less whether the interpreter thinks that she knows better, for legitimacy in a democratic polity begins with the ruler's recognition that the people need not be smart in order to matter. ${ }^{47}$

The constitutional vision of the demos, then, supposes that our government is the one that the Founders handed down. The interpreter who is guided by the popular imagination must select an interpretive method that exerts pressure (no perfect fit is possible) on the federal government to confine itself to a set of institutional arrangements substantially continuous with the original design of the Founders whom the popular imagination extols. This is what I mean by the de-evolutionary tradition, and the de-evolutionary interpreter must do the hard work of ascertaining the postulates that undergird the clauses establishing the government's structure. The best clue to those postulates is the text and the structure that it fairly implies; but where these fail, conscious resort ought to be had to the history of the period of drafting and ratification. At the same time, the interpreter must never forget the goal-the discovery of the underlying postulates-and must never forget that interpretation is an imaginative and creative task, not a purely or mostly mechanical one. There is no hierarchy of meanings: text over structure, structure over history, or the like. On the contrary, the interpretive task is to meld the text, structure, and history-including the deep and rich political science of the Founding Generation-into a coherent whole, by immersion in the intellectual currents of the Founding Generation. Then, the interpreter must take this more profound understanding of the Founding Era and use it as a basis for analyzing whatever structural question might be in issue. For only then, at the end of all of this hard work, can the interpreter say to the parties and to her public, "In order to render our institutions substantially continuous with the arrangements envisioned by the Founders, the thing that we must do (or must not do) is this."

That much, and no more, is the task of the de-evolutionary interpreter. Considerations of expediency, desirability, or efficiency are beside the point; what matters is hardheaded, concrete reasoning about the constitutional document itself, the structure of gov-

${ }^{47}$ This paragraph is adapted from Carter, 102 Harv L Rev at 120-21 (cited in note 6). 
ernment that it creates, and the political science underlying that structure. The question for a court reviewing, say, the constitutionality of the War Powers Resolution, would not be "Is this a good idea or not?" or "Does this maintain some balance of power or not?" but "Is this consistent with the vision of the Founders or not?"

The method that I propose for resolving cases under the Political Constitution will burden our judges, because it will often require much more from a court considering a structural question than the swift, almost mechanical application of a phrase or two from Madison's notes and a paragraph from The Federalist that too often counts as settling "the intent of the Framers." The temptation to limit the search is plain, and the rationale not inconsiderable. The Framing, at least, was a discrete event. True, many of the sources, especially Madison's notes, cannot reliably do all that many de-evolutionists might ask. ${ }^{48}$ But the records, even if thin and of questionable reliability, are accessible and describe a debate that might at some points have occurred roughly as written. Ratification, on the other hand, was a traumatic, nationwide event, one that sparked strong, sometimes ugly debates in every corner of the young republic. Tracking down the shared understanding of the ratifiers-not only their precise imaginings, but the postulates of good government underlying them-is not an easy task.

But the burden must be borne; good judging will at times be arduous. And it was the public deliberation on ratification, not the secret argument over drafting, that created constitutional government. So an interpreter seriously concerned about the original understanding must dip into a history considerably larger (but also richer) than the skimpy accounts of the debate at Philadelphia in the summer of 1787 .

Still, quite apart from doubts about the reliability of the sources, doing what I suggest might sometimes turn out to be impossible; sometimes the de-evolutionist judge will simply be unable

48 For example, James Madison could not possibly have recorded more than a fraction of what occurred at the Convention, and it would be a terrible analytic error to assume that what he did record is a full account simply because it has survived. See James H. Hutson, The Creation of the Constitution: The Integrity of the Documentary Record, $65 \mathrm{Tex} \mathrm{L}$ Rev 1,33-35 (1986). In any event, Madison's notes were unavailable to the ratifiers, who actually turned the work of the Convention into fundamental law. See id at 2; and Paul Brest, The Misconceived Quest for the Original Understanding, 60 BU L Rev 204, 214-17 (1980). It is difficult to see why what amounts to a secret legislative history is entitled to probative value on the question of the original understanding of the lawgivers themselves. For a general discussion of these and related problems, see Carter, 102 Harv L Rev at 122-25 (cited in note 6 ). 
to discover any textual or historical evidence bearing on the question at issue. In such a case, for reasons beside the point of the current paper, it is appropriate for the court to abstain, to permit the other branches to fight the matter out, by declaring the question to be a political one. ${ }^{49}$

Judicial review in the de-evolutionary tradition should be distinguished from evolutionary review, through which the courts permit the other branches of the federal government to work out fresh institutional arrangements, quite unlike those contemplated at the Founding, in order to meet the fresh problems of a different era. ${ }^{50}$ Bowsher $v$ Synar ${ }^{51}$ and INS v Chadha, ${ }^{52}$ in which the Supreme Court struck down, respectively, the automatic sequestration provisions of Gramm-Rudman-Hollings and the legislative veto, exemplify the de-evolutionary tradition, because in each case, the Jus-

\footnotetext{
19 See Goldwater v Carter, 444 US 996, 1002 (1979) (plurality opinion). In the sometimes overly legalistic emphasis on asking which branch "really" holds a particular power, scholars (and, lately, politicians) too often overlook the fact that the Constitution creates a system of checks and balances, and that the Founders' vision encompassed the use by each of the political branches of all of its powers in battle with the others. So, for example, if the President seeks to impound money appropriated by the Congress, one option is litigation; but another is for the Congress to refuse to appropriate money desired by the President for some entirely different purpose. For rare scholarly recognitions of this possibility, see, for example, Charles L. Black, Jr., The Working Balance of the American Political Departments, 1 Hastings Const L Q 13, 15-16 (1974); and Peter M. Shane, The Separation of Powers and the Rule of Law: The Virtues of "Seeing the Trees", $30 \mathrm{Wm} \&$ Mary L Rev 375, 382-86 (1989). See generally Carter, 1987 BYU L Rev at 800-08 (cited in note 14).

so For a detailed discussion of the evolutionary tradition, see Carter, 1987 BYU L Rev at 722-35 (cited in note 14). For an assessment of its dangers, see id at 744-52. I recognize of course that in the absence of some institutional evolution away from the original design, the United States government would hardly be the powerful entity that it is today. In his comparison of the American and English constitutions, Richard Kay has put the point this way:

If the experience in the United States provides any guide, the answer must be that the rules themselves (meaning the limitations the rulemaker intended to establish) play a subordinate part in the formulation of constitutional limits, a part which diminishes as the time of the rules' enactment becomes more remote. Certainly, many of the best-known judgments of the United States Supreme Court-those which, arguably, have had the most significant effect on the operation of government-cannot comfortably be justified as the mere vindication of decisions already explicit or implicit in the Constitution as amended.
}

Richard S. Kay, Substance and Structure as Constitutional Protections: Centennial Comparisons, Public Law 428, 436 (Autumn, 1989). There is a distinction, however, between evolution in the objects of regulation and evolution in the manner of regulation. The first is an inevitable concomitant of societal complexity, and it is difficult to believe that the Founders did not envision it. The second is a reflection of an impatience with a legitimating structure of balanced and separated powers, and its abandonment, for reasons discussed in the text, weakens the government's claim of legitimacy by obscuring the source of its authority.

31478 US 714 (1986).

32462 US 919 (1983). 
tices expressly rejected arguments that the particular structural innovation in question was justified on grounds of public policy or necessity. Morrison and Mistretta provide recent examples of evolutionary review.

My preference for de-evolutionary review should not be taken to suggest that I imagine that a text, even a legal text, possesses a final, inherent, and correct meaning. On this point, somewhat to my surprise, I find myself concurring with the semioticians and their close cousins, the deconstructionists, who deny, albeit for somewhat different reasons, the possibility that a text possesses a single reading. ${ }^{53}$ Reading is a function of context; it is impossible to answer the question "What does this text mean?" until the interpreter first asks herself "Why do I want to know?" Once one selects an interpretive methodology, moreover, space will remain for play of the imagination. The most for which we reasonably can hope is that the selected approach will constrain the interpretive imagination, a point conceded in the field of legal interpretation even by strongly committed originalists. ${ }^{54}$ As Mark Tushnet has pointed out, however, an interpretive rule that says "Always advance the cause of socialism" certainly constrains. ${ }^{55}$ The legitimacy of a rule for interpreting legal texts might therefore begin with the notion of constraint, but can hardly end there. Thus, the insight that legal scholars ought to take from the post-structuralist movements in literary criticism is that the interpreter has a responsibility to justify the selected interpretation in terms extrinsic to the interpreted text. ${ }^{56}$

${ }^{83}$ A neat, readable introduction to semiotics is Terence Hawkes, Structuralism \& Semiotics (U Cal, 1977). A useful introduction to deconstruction, even if sometimes a bit harder for the uninitiated to follow, is Harold Bloom, Paul de Man, Jacques Derrida, Geoffrey H. Hartman, and J. Hillis Miller, Deconstruction and Criticism (Seabury Press, 1979). For a very different view, see E.D. Hirsch, Jr., The Aims of Interpretation (U Chi, 1976).

${ }^{54}$ See, for example, Robert Bork, The Tempting of America: The Political Seduction of the Law 167-70 (MacMillan, 1989).

${ }^{85}$ See Mark Tushnet, The Dilemmas of Liberal Constitutionalism, 42 Ohio St L J 411 (1981).

${ }^{56}$ See Frank Easterbrook, Legal Interpretation and the Power of the Judiciary, 7 Harv J L \& Pub Pol 87, 97 (1984):

A judge cannot expect obedience just because he announces what he thinks a wise and just result would be. He must always be prepared to give an answer to the question[s]: Why should other people pay attention? Why is the opinion any more binding than a law review article?

For an analogous conclusion from a very different starting point, see Mark V. Tushnet, Following the Rules Laid Down: A Critique of Interpretivism and Neutral Principles, 96 Harv L Rev 781 (1983). 
My claim, therefore, is not that the interpretive method that I propose is correct in some sense that transcends context, but only that it lends to adjudication under the Political Constitution a legitimacy that other modes do not. ${ }^{57}$ I recognize that the will of the Founders always has about it a somewhat musty, antiquated, even shabby air, like a quaintly decorated table that is old enough to be a valuable antique but not sufficiently well preserved. And yet the single most pertinent fact about an old table is that it has survived: They could build in those days! we tend to say, with some surprise.

In the popular imagination, the Founders, too, could build, and what they built, however musty, still survives. If the courts allow governmental arrangements that run sharply contrary to the original design, they are in effect drawing upon an allegiance of the people gained by implying an institutional continuity that does not exist. This, in turn, amounts to preserving faith through a lack of candor. But the interpreter inclined to prevaricate must bear in mind the risk to legitimacy; for subterfuges, as Guido Calabresi has put it, "are always dangerous, rarely can be intentionally chosen, and can work only when they are not simply lies."

De-evolutionary review ties up all of these loose ends. (For reasons that should now be clear, I am disturbed when I read that what I have in mind is "originalism" or "formalism"-not that I consider either one an insult.) In the majority of structural cases, a de-evolutionary form of review will lead to relatively determinate answers; that is, different interpreters applying the test in good faith will tend to reach similar results. ${ }^{69}$ By contrast, what I have

${ }^{37}$ See also Schauer, 58 S Cal L Rev at 436-40 (cited in note 36). My Yale colleague Don Elliott, who considers my argument "circular," see Elliott, 57 Geo Wash L Rev at 507 n 5 (cited in note 13), argues that while I "may be right that literal application of the structural provisions of the Constitution legitimates judicial review," nevertheless, "it is the wrong kind of judicial review that gets legitimated." Id at 530. I will let the reader judge whether my views, whatever their flaws, are circular. As to the rest, I hardly consider my approach a "literal application" of anything, but assuming that phrase to be a slip of Professor Elliott's word processor, I will readily concede that reviewing courts might choose from a variety of approaches-including the creative interpretation that Elliott himself advocates or my own preference for immersion in the political science of the Founding - but if the newly chosen method is not tied closely to the text, structure, and history of the Constitution, then far from being the "right kind" of judicial review, it is not judicial review at all. For more on this point, see Carter, - Wash U L Q - (cited in note 39).

s8 Guido Calabresi, Ideals, Beliefs, Attitudes, and the Law 116 (Syracuse U, 1985). See also Alexander M. Bickel, The Least Dangerous Branch 92-93 (Yale, 2d ed 1986).

so I should make very clear that I do not conflate determinate results with value-free adjudication. See Robert W. Bennett, Objectivity in Constitutional Law, 132 U Pa L Rev 445 (1984). I make no claim that the choice for de-evolution in structural cases is value-free 
called the evolutionary approach almost inevitably must lead to balancing, and hence to indeterminacy. ${ }^{60}$ After all, if the balancing and policy analysis that the evolutionist prefers provided determinate results, the Congress would more often be unanimous.

The distinction in approach may also lead to a distinction in results: perhaps unsurprisingly, a search for the original understanding on the structure of government leads to suspicion about institutional innovations that seem to offend the delicate system of balanced.and separated powers crafted by the Founders, ${ }^{61}$ whereas a rule of deference allows the Congress to experiment with entities and procedures that might be more efficient and more politically responsive than those envisioned when the Constitution was written and ratified..$^{62}$ The results obviously matter; the methodology underlying them matters more. For what is too often forgotten about the Court's authority is what I mentioned briefly in the introduction: the Court does not only interpret, it also engages in dialogue. The interpretation is binding, in a way, but the dialogue is only one side of the conversation. When the Court declines to be de-evolutionary in construing the Political Constitution-or when, as seems to be the present case, the Justices cannot even agree on a theoretical approach - then the Court's side of the conversation ends up sounding garbled.

or somehow objective. See Carter, 1987 BYU L Rev at 781-82 (cited in note 14). On the contrary, even for the committed positivist, no theory of adjudication emerges as an ineluctable consequence of the existence of law. Compare G. Marshall, Positivism, Adjudication, and Democracy, in P.M.S. Hacker and J. Raz, eds, Law, Morality, and Society: Essays in Honour of H.L.A. Hart 132, 138-44 (Clarendon, 1977). Rather, the choice for de-evolutionary review itself furthers specific values, particularly the transcendent and legitimating value of consistency with the American people's image of how their republic is governed. (Apologies in advance to my old friend Martha Minow, who finds contextuality, not transcendence, the proper measure of legitimacy. See Martha Minow, Law Turning Outward, 73 Telos 79, 97-99 (1987).)

${ }^{60}$ See T. Alexander Aleinikoff, Constitutional Law in the Age of Balancing, 96 Yale L J 943, 972-82, 986-92 (1987).

${ }^{61}$ See Miller, 1986 S Ct Rev at 52-58 (cited in note 6); Sunstein, 101 Harv L Rev at 496-500 (cited in note 13).

${ }^{62}$ This is what I take to be the burden of my colleague Paul Gewirtz's assertion that the Constitution "creates living institutions to deal with public affairs in a deliberate, practical, and self-correcting way." Gewirtz, $30 \mathrm{Wm} \&$ Mary L Rev at 354 (cited in note 13). Gewirtz, I would say, is right in every aspect of this statement except its implications. After all, if one declines to be de-evolutionary about institutions, it is difficult to see how the Constitution can be said to "create" them. 


\section{Dialogue and Legitimacy}

Some years ago, in response to a Supreme Court decision he greatly disliked, Daniel Patrick Moynihan penned an important essay with the provocative title, What Do You Do When the Supreme Court is Wrong? ${ }^{63}$ The question is one that has dogged the nation since the Founding, for the Court has been wrong often, sometimes spectacularly so, and occasionally, as in Dred Scott, with dreadful consequences for the nation. ${ }^{64}$

Just about a decade before Moynihan's article, Albert 0 . Hirschman published his deservedly acclaimed monograph, Exit, Voice, and Loyalty. ${ }^{65}$ According to Hirschman, those who are dissatisfied with the performance of any entity, be it a corporation, a political organization, or government itself, face the choices of ceasing to patronize or obey (i.e., exit) or complain (i.e., voice). The dissatisfied are more likely to choose voice, he notes, if they believe that their complaints will make a difference in the entity's behavior at a relatively low cost to themselves. And a sense of loyalty to the entity, he adds, should also improve the prospect that the dissatisfied will choose voice.

Hirschman's analysis suggests an answer to Moynihan's question: When the Supreme Court is wrong, its constituents-the public and the public's representatives-are most likely to choose voice.$^{66}$ One reason for this is the widespread public sense that the entire government is, or should be, politically responsive. (One might suppose that the Supreme Court stands on a different footing in our political mythos, but for the tendency of the public to take offense when its views are not reflected in the Court's work ${ }^{67}$ and the related phenomenon of the public hoopla about the likely votes of nominees.) A second, perhaps more important, reason is loyalty: for the great majority of the American people, exit,

${ }^{63}$ Daniel Patrick Moynihan, What Do You Do When the Supreme Court is Wrong?, 57 Pub Int 3 (1979).

${ }^{64}$ I pass for the moment the question of what it means to say that the Court is wrong, although I will, of course, return to it.

${ }^{65}$ Albert O. Hirschman, Exit, Voice, and Loyalty (Harvard, 1970).

B6 The answer Hirschman predicts is similar to the one Moynihan himself reached, expressed in three neatly rhymed words: debate, litigate, and legislate. Moynihan, 57 Pub Int at 19-24 (cited in note 63).

${ }^{67}$ One particular proponent of this thesis has been Gregory A. Caldeira. See Public Opinion and the U.S. Supreme Court: FDR's Court-Packing Plan, $81 \mathrm{Am}$ Pol Sci Rev 1139 (1987); and Neither the Purse Nor the Sword: Dynamics of Public Confidence in the Supreme Court, $80 \mathrm{Am}$ Pol Sci Rev 1209 (1986). For a general discussion of the communication of and response to Supreme Court decisions, see Larry Charles Berkson, The Supreme Court and its Publics (D.C. Heath, 1978). 
whether conceived as physically leaving the country or as openly defying the courts, is unthinkable.

People are most likely to complain about the Court when they think it is wrong. They might complain through protest marches, scathing editorials, the ballot box, or-if they are legally inclined-the pages of the nation's law reviews. ${ }^{68}$ Whatever the people do, they complain; they talk, and hope that the Court gets the message; and, albeit with some trepidation, they await an answer, hoping perhaps that even if, as John Updike wrote of Ted Williams, gods do not answer fan mail, it might turn out that demigods answer hate mail.

And why not? The idea of dialogue has an impressive pedigree in constitutional theory. One may trace it to Thayer, to Lincoln, and earlier. ${ }^{69}$ Alexander Bickel, in trying in the sixties and seventies to cope with the work of the Warren Court, brought the dialogic model into contemporary debate. Ever since Bickel proposed the metaphor of the courts as interlocutors of the body politic, ${ }^{70}$ squads of theorists have argued the wisdom, as well as the limits, of the Bickelian metaphor. Some commentary has been critical, some approving; but what all of it has had in common is a sense that disobedience is at issue. The idea seems to be that when the courts hand down controversial decisions, they risk loss of scarce capital in the best case, open defiance in the worst. The image is one of a court mandating " $X$," and an aroused populace much preferring "not X."

But the model of dialogue as resting on command and defiance is too narrow to capture the richness of what Bickel surely envisioned. A dialogue is more than a competition for power; it is, as Bickel noted in The Morality of Consent, an "endlessly renewed educational conversation."11 Education need not be limited, on the one hand, to cases in which the Court must persuade a doubting public to go along, or, on the other, to cases in which the public must persuade the Court to change its view. Bickel argued that the

${ }^{68}$ As Philip Soper has pointed out, however, there is no reason to think that judges are impressed by law review critiques. See Philip Soper, A Theory of Law 2 (Harvard, 1984). Perhaps there is no reason that they should be.

${ }_{69}$ See James B. Thayer, The Origin and Scope of the American Doctrine of Constitutional Law, 7 Harv L Rev 129, 143-52 (1893), and Lincoln's momentous First Inaugural Address, March 4, 1861, in James D. Richardson, ed, 8 Messages and Papers of the Presidents 3206 (Bureau of National Literature, 1897).

${ }^{70}$ See Bickel, The Least Dangerous Branch (cited in note 58) (the first edition of this book was published in 1962); and Alexander M. Bickel, The Morality of Consent (Yale, 1975).

${ }^{71}$ Bickel, Morality of Consent at 111 (cited in note 70). 
Supreme Court and its public should talk to, not at, each other. Education, for Bickel, was "a conversation, not a monologue."

Bickel's archetype was the battle over school desegregation in the wake of Brown $v$ Board of Education, a battle in which, he seemed to conclude, the Court and the public had much to learn from one another. ${ }^{73}$ But the school desegregation battle illustrates only one form of dialogue. There, one sees a Court trying to awaken dissenting segregationists to the injustice of their cause while the segregationists themselves tried to persuade the Court that its ruling was wrong. To understand how narrow a vision of dialogue this is, turn the clock back six decades before Brown, to the era of separate-but-equal as enshrined in Plessy $v$ Ferguson. Under Plessy, the states were free to maintain segregated facilities, and many did. But some states chose not to. Some states desegregated schools and other institutions voluntarily. Successive presidents desegregated various parts of the executive branch, culminating in Truman's executive order desegregating the armed forces. ${ }^{74}$ Whatever their constitutional theories, these desegregators must have disputed the moral philosophy of Plessy.

That, too, represents dialogue-the dialogue that occurs when the government, far from defying a judicial ruling, declines to go as far as the ruling permits. The government may hold a power, whether by clear constitutional language or by judicial decree, and yet decide not to exercise it for any number of reasons: political pressures, for example, or judgments about whether a particular measure, even if desirable, is likely to be effective. Those reasons are all matters of practical politics. There is, however, another, more fundamental reason that a government might decline to exercise a power: because it believes that the Court was wrong to grant it.

The desegregators provide a good example. Even in that earlier age, politicians tended to assume an identity between constitutional meaning and the policies they preferred; so, if the desegregators thought segregation wrong, they very likely thought Plessy

72 Id. One need not be a Bickelian to employ this metaphor. See Paul Brest, Further Beyond the Republican Revival: Toward Radical Republicanism, 97 Yale L J 1623, 1629 (1988) (footnote omitted) ("Civic republicans must therefore work to re-create a space for citizens and non-judicial institutions to participate in constitutional discourse and decisionmaking.")

${ }^{73}$ Bickel, Morality of Consent at 110-11 (cited in note 70); and Bickel, Least Dangerous Branch at 244-57 (cited in note 58).

${ }^{74}$ Exec Order 9981, 3 CFR $\$ 617.1$ (1948). 
wrong as well. ${ }^{75}$ Similarly, in our age many states restrict access to abortion considerably less than the Supreme Court's decisions allow. The public outcry that greeted the Webster decision ${ }^{76}$ - the insistence by pro-choice forces that politicians who pressed for new abortion restrictions would be turned out of office-was designed as a message to the elected branches of government. Should those branches take the message to heart, dialogue would be joined with the Court, too: We do not want this power, the groan would come back up the Hill to First Street. Take it back, take it back!

As these examples suggest, dialogic models of judicial review are commonly envisioned as integral to the evolution of the meaning of the open-ended clauses that protect individual rights. Small wonder, given that the clauses themselves contain so few clues to their interpretation.77 Arguments about "originalism" versus "the living Constitution" provide scant guidance to practical judges who must decide how the perfectly opaque language of, say, the Due Process Clause applies to the dismissal of students from public schools. Despite many clever theories on how they can avoid it, judges necessarily consult their own moral sentiments in adjudicating cases under the clauses of this Natural Law Constitution. ${ }^{78}$ Naturally, one wants a constitutional theory that constrains the results that those morally sensitive judges might reach; ${ }^{79}$ still, although the matter is beyond the scope of this paper, there might

\footnotetext{
75 Nevertheless, some judges of very strong moral convictions struggled to separate, for example, their views on slavery from the decision on whether and how to enforce the fugitive slave laws. See Robert M. Cover, Justice Accused: Antislavery and the Judicial Process (Yale, 1975).

${ }^{76}$ Webster v Reproductive Health Services, $109 \mathrm{~S} \mathrm{Ct} 3040$ (1989).

77 The open-ended nature of many of the clauses of the original Bill of Rights strongly suggests that the Founders themselves might have envisioned a non-originalist judicial role. For controversial efforts to prove this hypothesis through examination of a sensible source-the political science of the Founding Generation-see, for example, Thomas C. Grey, The Origins of the Unwritten Constitution: Fundamental Law in American Revolutionary Thought, 30 Stan L Rev 843 (1978); H. Jefferson Powell, The Original Understanding of Original Intent, 98 Harv L Rev 885 (1985); and Sherry, 54 U Chi L Rev 1127 (cited in note 32 ).

${ }^{38}$ I do not claim a one-to-one correspondence between a judge's moral position and her legal position, I only suggest that the vaguer a constitutional clause, the more difficult the separation of personal values from adjudication. Although there are various ways of addressing this problem, the open-ended clauses of the Natural Law Constitution seem to undermine the pretense that some set of discoverable values can guide adjudication without requiring the judge to make any moral choices. On this point, the Critical Legal Scholars seem to me to have a very good argument. See, for example, Paul Brest, The Fundamental Rights Controversy: The Essential Contradictions of Normative Constitutional Scholarship, 90 Yale L J 1063, 1109 (1981); and Mark Tushnet, The Dilemmas of Liberal Constitutionalism, 42 Ohio St L J 412 (1981).

${ }^{79}$ Compare Bork, The Tempting of America at 250 (cited in note 54).
} 
be something to be said for the proposition that there are cases in which constitutional judges should engage in self-conscious moral reflection. ${ }^{80}$

This of course is hardly a new insight. What has not been given as much thought as it might deserve, however, is what the insight entails. The answer is, or ought to be, obvious: constitutional judges forced to take refuge in an assessment of moral truth should be far less certain of their rightness, and, in consequence, far more ready to listen to dissenting views, than judges who can find ways to limit their reliance on individual moral convictions. In short, constitutional judges who decide cases under the Natural Law Constitution should welcome the dialogic contribution of those who disagree with their views. ${ }^{81}$ Rights dialogue is an important and healthy part of the educational conversation, and there is some reason to think that judges often listen to it. ${ }^{82}$

What is often unrecognized is that dialogue should be equally welcome under the relatively more determinate structural clauses of the Political Constitution..$^{83}$ In a sense this might seem counterintuitive, especially if one believes (as I do) that choosing a rule that yields relatively determinate results is the key to legitimate interpretation of the Political Constitution, but not necessarily of the Natural Law Constitution. I have already explained why the form of cautious originalism that I call de-evolutionary review is necessary to maintain legitimacy in government structure. Because judgments about the meaning of the Political Constitution can thus be made with greater certainty, there is less room for dialogue concerning their validity.

3o For a defense of this position, see Ronald Dworkin, Taking Rights Seriously 22-45 (Harvard, 1977). I like the way that Linda Hirshman has phrased the point:

If the Court does not base decisions such as Roe $v$. Wade in some textual authority more convincing than the Court used in the opinion, one can defend such decisions only on the grounds that judges may occasionally impose their personal values of substance in the admittedly undemocratic exercise of judicial review. Two responses were possible, and each has been tried. One might either attempt to duck the battle by more securely lacating decisions in, for instance, the language of the equal protection clause, or one could bite the bullet and defend the judge's role as occasional moral arbiter.

Linda R. Hirshman, Bronte, Bloom, and Bork: An Essay on the Moral Education of Judges, 137 U Pa L Rev 177, 183 (1988) (footnotes omitted).

${ }^{81}$ For a more detailed elucidation of this point, see Stephen L. Carter, The Dissent of the Governors, 63 Tulane L Rev 1325, 1347-61 (1989).

${ }_{82}$ For a thoughtful dissent from the idea that judges should engage in a rights dialogue with the other branches, see Earl M. Maltz, The Supreme Court and the Quality of Political Dialogue, 5 Const Comm 375 (1988).

${ }^{83}$ For an interesting discussion, see Louis Fisher, Constitutional Dialogues: Interpretation as Political Process (Princeton, 1988), especially chapter 7. 
But less room is not no room. The Court may still err, and the error may still be clarified through dialectical interchange. The difference between dialogue under the open-ended clauses of the. Natural Law Constitution and dialogue under the structural clauses of the Political Constitution is that the structural dialogue is subject to special constraints necessitated by the special nature of judicial review under the Political Constitution. I have already explained why judicial review under the structural clauses should be guided by an understanding of the nature of those clauses. The same understanding that limits selection of interpretive rules also limits the range of available dialogic responses, and it is in that sense that the dialogue itself is constrained.

In particular, the "I just don't like this result" form of dialogue that may sometimes (but not always) be an appropriate critique of an interpretation of the Natural Law Constitution is irrelevant under the Political Constitution. ${ }^{84}$ So is the protest that a particular institutional innovation represents good or bad policy, ${ }^{85}$ and Richard Posner's suggestion that the legitimacy of a particular structural rule be tested by comparing how well other countries have survived with it or without it. ${ }^{86}$ What these critiques have in common is that they accuse the Court of what might be called an extra-constitutional error; that is, the mistake that the Justices have made-and that they are called in dialogue to correct-is a mistake only when measured against a source that is not a part of the text, structure, or history of the Constitution. But all of them should be met by the courts with a thundering roar of "Beside the point!" because none of them can trump the arguments for judicial enforcement of the science of the Founding Generation. Yet a court may make other errors in structural cases, and when it does so, dialogue is often an appropriate means of calling it to account.

The more complex (and perhaps more common) structural mistake is what might be called "rule application error." This error occurs when the Court properly strives to be de-evolutionary, but misunderstands the history, in the sense that the structural vision

84 I discuss dialogue under the Natural Law Constitution in Carter, 63 Tulane L Rev at 1347-51 (cited in note 81).

${ }^{85} \mathrm{E}$. Donald Elliott has been particularly forceful in urging that the federal courts in general, and the Supreme Court in particular, adopt a vision of the judge as policymaker in separation of powers cases. See E. Donald Elliott, INS v. Chadha: The Administrative Constitution, the Constitution, and the Legislative Veto, 1983 S Ct Rev 125, 173-76; and Elliott, 57 Geo Wash L Rev at 530-32 (cited in note 13).

${ }^{86}$ See Richard A. Posner, Constitutional Scholarship: What Next?, 5 Const Comm 17, 18 (1988). 
of the Founding Generation points to a different answer than the one that the Court selects. The more troubling, if more straightforward, structural mistake might be called "rule selection error," and occurs when the Court selects the wrong interpretive rule. A Court considering a separation of powers case commits this error by eschewing de-evolution in favor of balancing tests and considerations of what is generally called public policy.

An example of a decision in which the Justices are often accused of rule application error is Myers $v$ United States, ${ }^{87}$ which held that the Congress could not prohibit the President from removing executive branch officials under certain not fully specified circumstances. According to some critics, the Court in Myers misunderstood the views of the Founders. ${ }^{88}$ (I take no position here on whether the critics of Myers are right or wrong.) Nowadays, with originalism so out of fashion in the academy, the Court's structural opinions are rarely subjected to de-evolutionary critiques. Nevertheless, it is still a fairly simple matter to point out structural opinions that are styled as legitimating opinions but that are not de-evolutionary at all, and thus are subject to rule selection error. In both Morrison and Mistretta, for example, the Court essentially ignored history and, on some points, even eschewed a close reading of the constitutional text.

Unlike the possible error that the Justices may commit when forced to make direct moral choices in order to decide some cases under the Natural Rights Constitution, the errors of rule selection and rule application go to method, not result. It is difficult to argue (although some have certainly tried) that judges possess a comparative advantage over legislators in making moral choices; that is one reason that it is important for judges adjudicating individual rights cases to listen carefully to dissenting voices, even when the dissent takes the form of direct defiance. ${ }^{89}$ But when judges turn to structural questions, they have, or ought to have, a considerable comparative advantage in legal analysis, not least because the constitutional arguments pressed by members of the Congress and by the President are likely to be colored by desires to gain advantage. (Notice how, according to whatever administration happens to be

87 272 US 52 (1926).

${ }^{83}$ See, for example, Louis Fisher, The Constitution Between Friends: Congress, the President, and the Law 64-67 (St. Martin's, 1978); and Thomas O. Sargentich, The Contemporary Debate About Legislative-Executive Separation of Powers, 72 Cornell L Rev 430, 434-38, 460-64 (1987).

89 See Carter, 63 Tulane L Rev at 1356-59 (cited in note 81). 
in office, every bill that forces the President to do what he is disinclined to, or prevents him from doing what he wants, turns out to be unconstitutional.) So political actors should pay close attention to judicial pronouncements on their innovations-which is not the same as saying that they must always give the courts the final word.

The courts are not the same as the Court, and different degrees of dialogic deference may be due to each. This distinction surely motivates Samuel Estreicher and Richard L. Revesz in their quite sensible suggestion that administrative agencies and intermediate appellate courts should be viewed as "participants in a process of national law development in which neither set of actors has the final say." relationship between agencies and the intermediate courts, each brought into the regulatory process by a Congress apt to overrule either or both at any time, justifies the government's controversial practice of "intracircuit nonacquiescence"-that is, repeating in one circuit a legal position already advanced and rejected in another. Intracircuit nonacquiescence should have a considerable appeal to the advocate of dialogic interchange, for it keeps open the conversation on statutory interpretation in the same way that other dialogues may keep open the conversation on constitutional interpretation..$^{91}$

\section{Legitimating Opinions}

Liberal political theory is a story about constraining the form of popular rule known as democracy. It does this by specifying a set of principles that the mob-in-parliament-that is, the elected government-cannot violate. Traditionally, these principles have entailed specific processes through which the government's public, the demos, can work its will. Legitimate exercises of authority, then, are limited as an initial matter to those that follow the correct procedures. In addition, the principles of liberal theory (espe-

so Samuel Estreicher and Richard L. Revesz, The Uneasy Case Against Intracircuit Nonacquiescence: A Reply, 99 Yale L J 831, 831 (1990).

91 For a sense of the debate, in addition to the Estreicher and Revesz article cited in note 90, compare Samuel Estreicher and Richard L. Revesz, Nonacquiescence by Federal Administrative Agencies, 98 Yale L J 679 (1989), with Matthew Diller and Nancy Morawetz, Intracircuit Nonacquiescence and the Breakdown of the Rule of Law: A Response to Estreicher and Revesz, 99 Yale L J 801 (1990). See generally Cynthia R. Farina, Statutory Interpretation and the Balance of Power in the Administrative State, 89 Colum L Rev 452 (1989). 
cially in its contemporary incarnations) entail a set of rights on which the government is not permitted to trample.

Constitutional theory lies at the intersection of liberal political theory and the liberal theory of law. Constitutional theory governs constitutional interpretation and, therefore, ultimately controls the structure of government, the arena in which politics is played out. This point is vital to an understanding of the nature of what I call constitutionally improper government actions. In our ordinary image of politics, the government acts through will and is determined to accomplish its ends through any means that the courts are likely to sustain. Put otherwise, the only argument that might sway a resolute majority is the claim that the majority's preference is unconstitutional. That argument, if convincingly put, should slow the majority and perhaps even stop it in its tracks, a sensible metaphor since putting the brakes on majority rule is precisely what a written Constitution is for. ${ }^{92}$

This model is of course too simple. Constitutional courts exist not merely to say to the majority, "No, you may not." Sometimes-much more often, in fact-the courts instead say to the majority, "Yes, you may." In The People and the Court, one of the masterworks of constitutional scholarship, Charles Black calls the signaling of approval the "legitimating function" of judicial review. ${ }^{93}$ By playing this legitimating role, courts reassure the populace that it is indeed being governed in accordance with the forms of constitutional law. Says Black:

I think the legitimating function of the Supreme Court is one of immense-perhaps vital-importance to the nation. I do not see how a government of limited powers could live without developing some agency for performing this function. The Supreme Court has actually attained acceptance in this role, in satisfactory measure. To devise another structurally plausible way of getting this job done would be an immensely difficult task, and to bring about its actual acceptance would be not only difficult but quite chancy. ${ }^{94}$

A government of limited powers could scarcely exist without a legitimating institution, and Black is surely correct to suggest that the Supreme Court has "attained acceptance" in its role as legitimator. Whatever was true at the time of the Founding, the wide-

92 See Bickel, Least Dangerous Branch at 16-21 (cited in note 58).

${ }^{93}$ See Black, The People and the Court at 56-86 (cited in note 3).

94 Id at 66-67. 
spread expectation as we near the end of the twentieth century is that disputes over constitutionality are referred to the federal courts, where the Supreme Court has the final word: final in the sense that there is no appeal, and final in the sense that it cannot be disobeyed. ${ }^{95}$

The legitimating function, then, in addition to its structural importance, necessarily involves the exercise of power. To say that the Supreme Court of the United States has legitimated the contemporary model of independent administrative government is to make not only a legal statement but a political one as well. The effect of the statement is to disarm opponents of broadly delegated power who wish to rest their opposition on constitutional grounds instead of assailing the wisdom of particular policy choices. "But the Court has decided the question," the supporter of a new and expansive delegation can say, and that is the end of the matter.

Whether that ought to be the end of the matter is an interesting and important inquiry to which I will turn my attention in a few pages. First, however, it is useful to ponder further the question of what makes an opinion a legitimating one. Or, to put the point another way, when the supporter of a policy says, "But the Court has decided the question," is it enough that the decision has been made, or do the arguments pressed in support of the decision also matter?

The modern view, of course, is that judicial review is entirely a story of power: that the courts can, in essence, rule on whatever grounds they please, and the people simply will (or should) obey. ${ }^{96}$ Constitutional law is like law of any other kind: one knows what the law is because an authoritative decisionmaker has said so. ${ }^{97}$ An approach of this nature, however, strips judicial review of every attribute that differentiates the work of the courts from the work of the legislatures. I am reminded of what John Ely has said about Roe $v$ Wade: the problem is not that it is bad constitutional law, but that it is not constitutional law in any recognizable sense. ${ }^{98}$ Putting to one side the question whether Ely's criticism is fair with

9s The ability of the Supreme Court to command obedience may be related to its success in identifying trends in public opinion, particularly on issues relating to individual rights. See David G. Barnum, The Supreme Court and Public Opinion: Judicial DecisionMaking in the Post-New Deal Period, 47 J Politics 652 (1985).

${ }^{96}$ For a somewhat overargued statement of this proposition, see Bork, The Tempting of America at 351 (cited in note 54).

${ }^{97}$ Compare Fiss, 34 Stan L Rev at 755-58 (cited in note 26).

98 John Hart Ely, The Wages of Crying Wolf: A Comment on Roe v. Wade, 82 Yale L J 920, 935-37 (1973). 
respect to that particular case, it plainly carries rhetorical power, and the power must stem from a sense that there are ways in which courts, as against other branches of government, are expected to act. ${ }^{99}$

In general, constitutional decisions that are closely tied to the text, structure, and history of the Constitution are more deserving of respect than those that are not. In the particular case of adjudication under the relatively determinate structural clauses of the Political Constitution, the highest degree of respect should be accorded those decisions that fall within the de-evolutionary tradition. If the Supreme Court, reasoning in a de-evolutionary manner, prohibits a particular institutional innovation on constitutional grounds, the Congress and the President should be reluctant to press it; and if they do so, they must recognize that unless they are able to make a persuasive case for rule application error, they are acting lawlessly.

At what might be called the opposite extreme were it not so disturbingly common, the Court issues a decision allowing a particular innovation but couches its opinion in the evolutionary language of efficacy or efficiency or deference to congressional policy choices. Facing a decision of this kind, a political actor betrays no disrespect for legal process if she nevertheless questions the constitutional warrant for the innovation. So while the political branches should be reluctant to force on the Court an institution that has been declared unconstitutional on de-evolutionary grounds, they should show no similar reluctance in refusing, on explicitly constitutional grounds, to create an institution that the Court has approved in an opinion lacking adequate de-evolutionary explanation.

This idea should hardly be shocking. It isn't even new. Professor Black, in his discussion of the Supreme Court's legitimating function, points out that while McCulloch $v$ Maryland might be said to have answered the constitutional question that had dogged the Bank of the United States since its inception, the political reality was more complex. ${ }^{100}$ President Andrew Jackson vetoed the rechartering of the Bank in 1832. In his veto message, says Black, Jackson "attacked the theory that the decision of the Court was binding on him in his legislative function of approving or disap-

${ }^{29}$ For an insightful presentation of the claim that acting like a court does not necessarily entail obedience to law in the positivist sense, see Steven D. Smith, Why Should Courts Obey the Law?, 77 Georgetown L J 113 (1988).

${ }^{100}$ Black, The People and the Court at 81 (cited in note 3 ). 
proving bills passed by Congress." hardly an astonishing proposition, if one believes (as Black does, and as I do) that "the President can veto for any reason that appeals to him." "102

However, a study of the veto message suggests that there was more to Jackson's position than a belief that he, as President, possessed the freedom to act as he chose in his legislative capacity. The message was an attack on McCulloch itself. According to Jackson, the Bank possessed powers that were "unauthorized by the Constitution, subversive of the rights of the States, and dangerous to the liberties of the people." ${ }^{103}$ True, wrote Jackson, the Supreme Court has sustained the constitutionality of $a$ Bank of the United States, but not every constitutional question raised by the rechartering of the Bank had been present in $\mathrm{McCulloch}{ }^{104}$ Besides, he argued, even if the opinion in McCulloch had "covered the whole ground" of the new Bank, "it ought not to control the co-ordinate authorities of this Government." ${ }^{105}$ Why not? Because

[t]he opinion of the judges has no more authority over Congress than the opinion of Congress has over the judges, and on that point the President is independent of both. The authority of the Supreme Court must not therefore be permitted to control the Congress or the Executive when acting in their legislative capacities, but to have only such influence as the force of their reasoning may deserve. ${ }^{106}$

This well-known passage might easily be misread to support the notion that President Jackson counseled executive defiance of the Court when the Court is unpersuasive in its reasoning. In light of what I have said previously about the importance of the reason-

101 Id.

${ }^{102}$ Id. For a general discussion of the veto power, including grounds cited by the Presidents for its exercise over the years, see Chester James Antieau, The Executive Veto (Oceana, 1988).

${ }^{103}$ Andrew Jackson, Veto Message, July 10, 1832, reprinted in Veto Messages of the Presidents of the United States, S Misc Doc 49-53, 49th Cong, 2d Sess 88 (1886) ("Jackson Veto Message").

${ }^{104}$ Id at 93-94. Among the aspects of the Bank to which Jackson objected on constitutional grounds and which, he said, the Court did not consider in $\mathrm{McCulloch}$, were the delegation of the congressional power to regulate the currency, see id at 98 , and an interference with the state taxing power, see id at 98-100. He also argued that although the constitutionality of the Bank was supported in part by its location within the executive branch, the executive "neither needs nor wants an agent clothed with such powers and favored by such exemptions." Id at 101.

105 Id at 94.

106 Id. 
ing of structural opinions, the notion is one with which I am obviously sympathetic. But in its context, that isn't what the passage says at all. Jackson is not suggesting the enactment of legislation that the Court is likely to strike down. He is suggesting that the Congress refrain from passing and the President refrain from signing legislation that the Court is likely to sustain-if, in the judgment of the political branches, the legislation is nevertheless contrary to the Constitution. That was the point of the defense of the veto message later offered by Roger $\mathrm{B}$. Taney, who actually wrote it. ${ }^{107}$ It is also the only sensible construction of the point that Jackson makes two paragraphs later when, after noting the reliance of $\mathrm{McCulloch}$ on the Necessary and Proper Clause, he adds:

Without commenting on the general principle affirmed by the Supreme Court let us examine the details of this act in accordance with the rule of legislative action which they have laid down. It will be found that many of the powers and privileges conferred on [the Bank] cannot be supposed necessary for the purpose for which it is proposed to be created, and are not therefore means necessary to attain the end in view and consequently not justified by the Constitution. ${ }^{108}$

Thus, Jackson's veto message comes down to the proposition that the Court's approval of a measure does not bind the President and the Congress to suppose, when a similar measure later arises, that no constitutional objections can be raised. In Jackson's view, then, the legitimating role that Professor Black envisions for the Court is essentially for public consumption; it assures the people that all three branches are in accord. But a legitimating opinion by the Court does just that, and no more-it does not bind or command. No matter what the Court might have concluded in its legitimating opinion, says Jackson, when the issue that provoked it arises again the political branches are free to oppose the measure on the ground that it violates the Constitution.

My only quarrel with President Jackson is that, as I have said before, the reasons adduced by the Supreme Court in its legitimat-

${ }^{107}$ Taney, who would later be Chief Justice, found the brouhaha over Jackson's argument surprising. "[N]o intelligent man who reads the message can misunderstand the meaning of the President," Taney wrote. "He was speaking of his rights and his duty, when acting as a part of the Legislative power, and not of his right or duty as an Executive officer." Quoted in Charles Warren, 1 The Supreme Court in United States History 763 (Little, Brown, rev ed 1926).

${ }^{108}$ Jackson Veto Message at 95 (cited in note 103) (emphasis added). 
ing opinion matter; so do the reasons adduced by opponents who challenge the measure on constitutional grounds. The bank bill veto message, insofar as it is a rejection of judicial supremacy in the strong sense that I have suggested, would have rested on a more solid foundation had Jackson made plain what aspects of the reasoning of $\mathrm{McCulloch}$ he found unconvincing. ${ }^{109}$ Translated to our present age, the point would be that a legitimating opinion on a question of structural constitutional law ought to be cast in explicitly de-evolutionary language. An opinion so crafted would carry the dialogic weight that Morrison and Mistretta, for example, do not.

If, however, the purported legitimating opinion is not cast in the language of de-evolution, then it is far less apparent how it can be said to legitimate anything. True, a judicial decision will still exist, and proponents of the challenged measure can still respond to the constitutional claim with the cry, "But the Court has decided the question." The difficulty is that if the "legitimating" opinion is not tied to the text, structure, and history of the Constitution, the opponents might be justified in firing back with, "Yes, so what?" For the principal uniqueness of judicial review cannot possibly be that it is final; finality, after all, is a judgment not on power, but on precedence. Finality is simply the privilege of speaking last. The uniqueness of the judicial role surely rests instead on the singular expertise of the courts, and their concomitant responsibility to give reasons-and reasons of a particular sort-to justify their actions. ${ }^{110}$

Justice Jackson was wrong to suppose that the Supreme Court Justices "are infallible only because we are final."111 $\mathrm{He}$ should have said "We are infallible only when we are final." Alexander Bickel was right in considering the judiciary to be the least dangerous branch, because the Supreme Court speaks last only when the rest of the government lets it speak last. And the decision of the rest of the government to let it speak last ought to rest not simply on the fact that the Court has spoken, but on the authoritative

108 Other critics of $M c C u l l o c h$, however, specified at some length the reasons that, in their view, the Court had misconstrued or misstated the applicable doctrines. See Warren, Supreme Court in United States History at 509-10, 514-27 (cited in note 107).

110 See Edward H. Levi, An Introduction to Legal Reasoning (U Chicago, 1949); and Richard A. Wasserstrom, The Judicial Decision (Stanford, 1961). Compare Frederick Schauer, Formalism, 97 Yale L J 509, 544-48 (1988) (defending "presumptive formalism" as a restriction on judicial freedom). See also Bickel, The Least Dangerous Branch at 202-07 (cited in note 58).

${ }^{11}$ Brown $v$ Allen, 344 US 443, 540 (1953) (Jackson concurring in the result). 
grounding of the Court's reasoning. ${ }^{112}$ Or, as Philip Kurland has put the point, since the Court lacks the practical power to impose its views, "it would do well to be convincing."113

\section{Constitutional IMPROPRIETIES}

American constitutional government in the late twentieth century is amenable in nearly all of its parts to judicial admonition, correction, and guidance. Put otherwise, almost no clause of the Constitution has proved too opaque, no corner of the federal bureaucracy too small, no governmental procedure too trivial, to receive judicial scrutiny. We retain a system of balanced and separated powers, but it is not quite the one that the Founders envisioned; it has become more legalistic, the role of the courts more intrusive, the system itself more distant from the original model, in which the political branches parry and thrust (or, in Roosevelt's metaphor, call the plays) while the courts act as referees.

The model of elected government as unadorned majority will supposes that whatever the majority wants to do, it should do, as long as the courts have found no constitutional violation. But that model, as I have already shown, is inadequate. Legislators have a responsibility to make their own assessments of constitutionality when the courts have been silent. But as President Jackson pointed out, there is no evident reason that the responsibility should cease simply because the courts have spoken. ${ }^{114}$ Even when the courts, as final interpreters, have already sustained a new institutional form, the members of the Congress and, after them, the President, must be mindful of the possibility that the institution is nevertheless constitutionally improper.

What I call a constitutionally improper government action-or, for short, a constitutional impropriety-is an official act

212 See Easterbrook, 7 Harv J L \& Pub Pol at 97-98 (cited in note 56). It is not my intention in this brief discussion to oversimplify the complex problem of civil disobedience as a means of dialogue, particularly when the law being disobeyed is a judicial order and the "person engaging in the civil disobedience" is a government official who finds the reasoning behind the order unpersuasive. I have addressed the problem in more detail in Carter, 63 Tulane L Rev at 1347-59 (cited in note 81), and I am currently at work on a book-length treatment of the problem of disobedience by government officials, tentatively entitled The Dissent of the Governed: A Theory of Constitutional Obligation.

${ }^{113}$ Philip B. Kurland, Politics, the Constitution, and the Warren Court 95 (U Chicago, 1970).

${ }^{14}$ Jackson isn't alone. Brest doesn't believe it either. See Paul Brest, The Conscientious Legislator's Guide to Constitutional Interpretation, 27 Stan L Rev 585, 589 (1975). 
that a court ought not or does not forbid but that nevertheless is contrary to the spirit of the document, as reflected in the document's history and in its role in the constitutional story that We the People of the United States, tell about ourselves. A constitutional impropriety, although not identical in a positivist sense to an unconstitutional act, is every bit as offensive to the Constitution, and ought therefore to be every bit as troubling to those who care about constitutionalism.

Many constitutional improprieties involve rights that We the People (or many of us anyway) might think of as fundamental. For example, suppose that President Abe nominates Judge Barbara for a seat on the Supreme Court. Suppose further that Barbara is a black woman, and that there is in the Senate sufficient racism and sexism to sway a few key votes against her. (Others oppose her on what nowadays are unfortunately considered legitimate grounds, predictions about the way she is likely to vote.) Barbara's nomination is defeated. Once the evidence of improper motivation turns up (and in this ethics-hungry age, it is difficult to imagine that it would not) Barbara might sue, arguing that the Senate's action has violated her rights under the Fifth Amendment. (Not, of course, the Fourteenth-let's be doctrinally precise! $)^{115}$

Were some Senators motivated by racism or sexism, their votes would be morally inexcusable, but that does not mean that a constitutional claim would exist. ${ }^{116}$ On the contrary, a judicial decision holding Barbara entitled to her commission because of the grounds on which the votes were cast, while magnificent political theater, would be terrible constitutional law. ${ }^{117}$ If there is in our separation of powers jurisprudence a place for the political question doctrine, it is surely in the process of nomination and confirmation. ${ }^{118}$

${ }^{115}$ See Bolling v Sharpe, 347 US 497 (1954).

"16 See Henry P. Monaghan, Our Perfect Constitution, 56 NYU L Rev 353 (1981) (arguing that the Constitution "guarantees only representative democracy, not perfect government," id at 396).

${ }_{117}$ In this sense, I trust that Marbury v Madison, 5 US 137 (1803), a structural case, is fully distinguishable.

${ }_{118}$ See Stephen L. Carter, The Confirmation Mess, Revisited, - Nw U L Rev (forthcoming, 1990). I have elsewhere argued that two rules should govern the application of the political question doctrine in separation of powers cases. First, the courts ought to declare a question political if a review of the relevant history convinces them that judicial interference with another department's discretion would be contrary to the original design. Second, the courts ought to declare a structural question a political one if they are unable to find an answer that can be justified in de-evolutionary terms. See Carter, 1987 BYU L Rev at 800-08 (cited in note 14). 
And if, Barbara loses her lawsuit because of the political question doctrine it naturally follows that the Senate possesses the raw constitutional power to reject a nominee on racist and sexist grounds. ${ }^{119}$ To say that the power exists is not, however, to say that the power ought to be exercised. On the contrary, to oppose a nominee because of her sex or race cuts against the grain of twentieth-century constitutional jurisprudence, or, to put the matter in somewhat loftier terms, it runs counter to the spirit of the Constitution. And for that reason, a senator contemplating a vote on racist or sexist grounds ought to refrain, even though no court would or should interfere (and even if-who knows? - the senator's constituents might actually applaud the vote). The senator's vote might be constitutionally permissible, but it nevertheless would be constitutionally improper.

The notion of constitutionally improper actions flows from the familiar propositions that the Constitution equally binds all branches of federal government and that each branch necessarily carries a part of the interpretive burden. We cannot consult the courts constantly, on all details of governance, and it would mark the failure of our republic were we to try. As Paul Brest has pointed out, the idea of judicial exclusivity in constitutional interpretation is profoundly undemocratic:

The practice of judicial review is sometimes said to relieve Congress of the obligation to determine the constitutionality of its enactments. But nothing in Marbury implies that only the courts can interpret the Constitution. Indeed, Marbury's reliance on the Constitution as supreme law, paramount to ordinary legislation, suggests how absurd the notion of judicial exclusivity is: To suggest that Congress need not consult the supreme law of the land is analogous to asserting that individual citizens need not consult the law before they act. To be sure, citizens sometimes break the law, subject only to the risk of sanctions if they are caught. But it would be perverse to take this to mean that they are not obligated to obey the law. Much as the income tax system depends on citizens' honesty and voluntary compliance, constitutional de-

119 Efforts to make less than this of the political question doctrine have not generally succeeded. For a tidy refutation of most of them, see Louis Henkin, Is There a "Political Question" Doctrine?, 85 Yale L J 597 (1976). But see Goldwater v Carter, 444 US 996, 100205 (1979) (plurality opinion). 
mocracy requires legislators to abide by the Constitution, even if they will not be caught and punished if they disobey it. ${ }^{120}$

The distinction between the general idea of a legislative obligation to make assessments of constitutionality and the concept of constitutional improprieties lies in the idea that an enactment may offend the legislator's sense of the spirit of the Constitution without being considered, in a positivist sense, unconstitutional.

My call for legislators to uncover the spirit of the Constitution should not be taken to suggest that I imagine it an easy matter to determine, in a positivist way, what the spirit of the Constitution is. But doing so is nevertheless a legislative responsibility, one that falls at all times upon the Congress, and one that falls upon the President when he acts in a legislative capacity. Besides, assessing the spirit of the Constitution might not be as difficult as it appears. The story of President Abe and his nomination of Judge Barbara provides one example, but the fundamental rights field is readily mined for others.

Consider, for example, Justice Douglas's majority opinion in Griswold $v$ Connecticut, ${ }^{121}$ a decision occasionally criticized as lacking constitutional moorings. According to Justice Douglas, a constitutionally protected "zone of privacy" may be found in "penumbras, formed by emanations from" the "specific guarantees in the Bill of Rights." ${ }^{222}$ According to the critics, this is not an acceptable form of constitutional interpretation. I do not choose to enter that argument here; I would suggest, however, that the criticism, if it carries any validity at all, is properly directed only at judicial interpreters. Justice Douglas's opinion exemplifies reasoning about the spirit of the Constitution, and in that sense represents precisely what legislators ought to do. Thus even were Griswold one day reversed, a constitutionally sensitive legislator might well decide that legislative restrictions on birth control technology are constitutionally improper.

Still, in an era when the federal courts (and, for that matter, the news media) tend to patrol the borders of fundamental rights with some care, it is not likely that many government officials will be faced with a choice quite so stark as in the example of the racist senator's response to Abe's nomination of Barbara. ${ }^{123}$ The example

120 Paul Brest, Congress as Constitutional Decisionmaker and Its Power to Counter Judicial Doctrine, 21 Ga L Rev 57, 63 (1986) (footnote omitted).

121381 US 479 (1965).

122 Id at 484.

${ }^{123}$ This has quite recently in our history not been true, and indeed, but for the tone of 
may even seem somewhat implausible, and if it does, the reason may be precisely that the vote against Barbara would be constitutionally improper. Some constitutional improprieties strike at the heart of the American mythos, and in an era when moral and legal judgments so often seem to mix, it is quite natural that most Americans would quail at the thought that their representatives might act in ways that our continuing constitutional story teaches are wrong. More plausible, surely, is the possibility that the Congress (and perhaps the President) will take advantage of a series of broadly worded opinions of the Supreme Court to alter the structure of the federal government, and with it, the system of checks and balances that is designed to keep that government from becoming tyrannical. ${ }^{124}$

The idea of a structural impropriety might seem a bit startling. After all, when most Americans think about their constitutional rights at all, they tend to think in terms of what they are free to do without government interference. The idea of a constitutional right to a particular government structure is not nearly as deeply ingrained in the American constitutional ethos. Just like a fundamental rights decision, a structural decision can run against the grain of the Constitution's spirit. The principal distinction is that although the Natural Law Constitution might have an evolutionary component (a question, I repeat, that is beyond the scope of this article), the Political Constitution should not. The spirit of the Political Constitution is the spirit of 1787 ; it is the liberty implied in the structure of government, not the specific rights secured against government abuse, that provides the continuity between the Founding generation and our own. If there is no continuity, then the claim of constitutional government is in the most important sense a big lie; what exists in its stead is a set of institutions without warrant in anything except the will of all three branches of the federal government. And if that is the way the world is to work-if the structural design of the Political Constitution is to be

the battle over the Bork nomination, I would venture to suggest that nothing other than racism could adequately explain the vehemence and personal character of many of the attacks on Thurgood Marshall when he was nominated as an Associate Justice in 1967. For my comparison of the Bork and Marshall confirmation hearings, see Carter, - Nw U L Rev at - (cited in note 118).

124 Separation of powers and checks and balances were historically very different concepts. See M.J.C. Vile, Constitutionalism and the Separation of Powers 33 (Clarendon, 1967). Part of the political science of the Founding was the combination of the two ideas in a system of balanced and separated powers. See Carter, 1987 BYU L Rev at 771-78 (cited in note 14). 
treated not as binding law but rather as a suggestion of a possible arrangement of government institutions-then one might also ask what source provides legitimacy for the three branches themselves.

This, surely, is the point, as well as the force, of Justice Scalia's insistence in Mistretta that the Congress could not simply delegate all of its legislative authority to the President and then adjourn. ${ }^{125}$ The reason that the Congress cannot do so has nothing to do with the best way of making public policy or deference to congressional judgment. On the contrary, the President might prove the more politically responsive decisionmaker, ${ }^{126}$ and he can certainly act with greater dispatch than the Congress. And as to deference, presumably if the Congress did it, the Congress meant to do it. ${ }^{127}$ The reason must be a structural, de-evolutionary one: this isn't the way the system was designed to function. The delegation of all legislative authority would be a constitutional wrong, and no "legitimating" opinion of the Supreme Court could make it into a constitutional right.

John Ely has suggested that "it can only deform our constitutional jurisprudence to tailor it to laws that couldn't be enacted," 128 a conclusion that would mean, in this case, that Justice Scalia's hypothetical is a non sequitur. I am not so sure that Ely is right, but his normative claim can, for present purposes, be placed to one side. The difficulty is with the positive claim, the assertion that there are statutes (particularly structural ones) that could never be enacted. As Erwin Chemerinsky has pointed out, for example, whatever the Founders might have thought of independent entities exercising executive functions, they probably did not expect sweeping delegation of legislative authority ${ }^{129}$ _but it has happened anyway. And as to Justice Scalia's hypothetical, is it unreasonable to imagine the Civil War Congress doing exactly what he supposes, delegating all of its authority to Lincoln? One might even argue that by implication, that is exactly what the Congress did.

The smaller delegations that are a part of the everyday life of the administrative state differ from these examples only in degree, not in kind; the Supreme Court, as authoritative constitutional in-

${ }^{125}$ Mistretta, $109 \mathrm{~S}$ Ct at 677 (Scalia dissenting).

${ }^{126}$ See Jerry L. Mashaw, Prodelegation: Why Administrators Should Make Political Decisions, $1 \mathrm{~J}$ L Econ \& Org 81 (1985).

127 See US Railroad Retirement Board v Fritz, 449 US 166 (1980).

${ }^{128}$ Ely, Democracy and Distrust at 183 (cited in note 34 ).

128 See Chemerinsky, 103 Harv L Rev at 53 (cited in note 17). See also Miller, $1986 \mathrm{~S} \mathrm{Ct}$ Rev at 54-55 (cited in note 6). 
terpreter and participant in constitutional dialogue, has the responsibility sooner or later to subject these independent entities to the same de-evolutionary rigor that other innovations, such as the legislative veto, have undergone. To do less fails to legitimate them, creating instead a constitutional climate in which "So what?" is an entirely adequate response to the Court's "legitimating" opinions.

It is no answer to a separation of powers challenge to independent agencies to say, as the Justices are fond of saying, that the Founders never intended a "hermetic seal" to divide the branches. ${ }^{130}$ The fact that the Founders might have expected some degree of overlap among the branches does not imply that every overlap is acceptable. ${ }^{131}$ The legislative veto cannot be made constitutional on the ground that the Founders expected some degree of intermingling of legislative and executive functions: one must still ask whether this intermingling is consistent with the original design. The same is true of Justice Scalia's hypothetical decision by the Congress to delegate all its authority to the President and then adjourn. Both would be structural wrongs.

The force of Justice Scalia's example comes in its recognition that what the government tries to do to private individuals is not all that matters. In fashioning a system of balanced and separated powers, the Founders understood that how the government does what it does matters too. ${ }^{\mathbf{1 3 2}}$ Tyrannical governments tend to intermingle and concentrate powers that ought to be separate. Such governments are without the checks and balances inherent in a separation of powers, and that lack of checks on the exercise of authority is what makes "dictator" a dirty word.

The correct answer to Justice Scalia's hypothetical has to be that a member of the Congress, no matter what judicial opinions

130 The "hermetic seal" language is from Buckley $v$ Valeo, 424 US 1,121 (1976) (per curiam), in which, among other things, the Justices struck down on separation of powers grounds a provision permitting the congressional leadership to appoint some of the members of the Federal Elections Commission. See also Industrial Union Dept. $v$ American Petroleum Institute, 448 US 607, 673 (1980) (Rehnquist concurring); INS v Chadha, 462 US at 951 (White dissenting); Bowsher $v$ Synar, 478 US at 714, 718 (Stevens concurring).

131 See Carter, 1987 BYU L Rev at 765-800 (cited in note 14); Krent, $74 \mathrm{Va} \mathrm{L} \mathrm{Rev} \mathrm{at}$ 1258-72 (cited in note 14); and Shane, $30 \mathrm{Wm} \&$ Mary L Rev at 379-81 (cited in note 49).

${ }^{132}$ This is the flaw in the otherwise fascinating separation proposal put forth by Jesse Choper, under which the federal courts would essentially dismiss as political any constitutional questions raised about the allocation of authority between the President and the Congress. See Jesse H. Choper, Judicial Review and the National Political Process 260-379 (U Chi, 1980). For my more detailed response to Choper, see Carter, 1987 BYU L Rev at 803-08 (cited in note 14). 
might exist and no matter what her views on the wisdom of assigning all legislative authority to the President, should feel free to say "I will vote against this delegation, even if a court has held it to be constitutional, because it is constitutionally improper." And for cases short of the hypothetical-radical restructurings of the relationship between the executive and legislative branches, delegations of substantial but finite amounts of power, and the like-the freedom must be the same. A legitimating judicial opinion should not stand in the way of a legislator's judgment that the act in question represents a constitutional impropriety.

And a conscientious legislator, as much as a court, can look for guidance to the de-evolutionary tradition, because the legitimacy implied in its reflection of American political iconography is as important to legislative as to judicial governance.

\section{Dialogue, Propriety, and the Legitimacy of the Administrative State}

What has all this to say about administrative government? Just this: it is not enough that the Congress sees advantages to a particular agency design, the President agrees, and the courts are willing to defer to political judgment. There is another question that all these actors must consider before the aura of legitimacy is bestowed upon the new design: whether the design is contrary to the spirit and history of the Constitution; that is, whether it is constitutionally improper.

Administrative agencies, entities independent of the direct control of either the President or Congress, have an impressive positivist pedigree: the courts have sustained them against nearly every important challenge. But for reasons that I have explained, the opinions sustaining them must be subjected to de-evolutionary scrutiny to determine whether or not they may be regarded as authoritatively legitimating. It turns out that none of the three decisions that can be said to establish the modern independence of the agencies-Humphrey's Executor, Morrison, or Mistretta-is written in a way that anchors the result firmly in text, structure, or history. In that sense, it can fairly be said that the Supreme Court has never handed down a truly legitimating opinion on the constitutional propriety of the independent agencies. For that reason, legislators and Presidents would be perfectly justified in treating the independence of the agencies as a constitutional impropriety.

The Reagan Administration could hardly have been happy with its going-away present from the Supreme Court, the decision 
in Mistretta $v$ United States. ${ }^{133}$ In Mistretta, the Justices voted 8 to 1 to sustain the constitutionality of the United States Sentencing Commission, an independent agency, ostensibly "in" the judicial branch, which issues guidelines that limit the sentencing discretion of federal judges. Since sentencing guidelines that bind seem legislative in character, and since the members of the Sentencing Commission are not under legislative or executive control, one conclusion that can be drawn from Mistretta is that the current Supreme Court is untroubled by delegations of legislative authority to essentially independent entities.

The Reagan Administration had argued to the Court that the power to issue sentencing guidelines, if not exercised by the Congress itself, had to be lodged in the executive branch. This claim, although rejected by the majority with the terse and somewhat mysterious observation that the power to set rules "becomes an executive function only when delegated by the Legislature to the Executive Branch," ${ }^{134}$ has a surface plausibility. Cass Sunstein has summarized the case for centralizing delegated power in the executive branch as resting on three factors: first, that the President is electorally accountable; second, that "[t]he President's institutional position is useful for coordinating the wide range of sometimes inconsistent legislation of the modern regulatory state"; and, third, that the President is able "to energize and to direct regulatory policy in a way that would be difficult or impossible if that policy were set individually by agency officials." ${ }^{135}$ These arguments, while of obvious policy-analytic appeal, of course carry no de-evolutionary weight. (A possible exception is the first, which might be recast as a reflection of the Founders' concern that political decisions be made by electorally accountable decisionmakers.)

Another possible basis for the Reagan position is an argument from constitutional language and structure. The first sentence of Article II, vesting in the President "All" executive authority, is the obvious place to start. The "take care" clause is a useful addition. How, after all, can the President take care that the executive power vested in him by the Constitution be faithfully executed if he is unable to control those in whom the Congress chooses to vest it? But that argument, for all that it might say about the transfer of executive authority to independent entities, says nothing about

133 109 S Ct 647 (1989).

134 Id at $662 \mathrm{n} 14$.

${ }^{135}$ Sunstein, 101 Harv L Rev at 453 (cited in note 13). 
the delegation of legislative authority; after all, making the laws is not the same function as seeing that they are faithfully executed.

One might of course go to the history, of which there is a bit, ${ }^{136}$ or one might finally go to the structure. One might argue, for example, that even if the contours of congressional power to assign legislative or executive authority to an independent entity are unclear, matters are different when the Congress and the President have agreed on an allocation of legislative authority into the executive branch, and a wise and sensitive Supreme Court will disturb the allocation at its peril. After all, did not the Founders expect the executive to act with energy and dispatch when the legislature could not? Did not Justice Jackson, in his famous concurrence in the Steel Seizure Case, point out that when the Congress has authorized the President to act as he has, "his authority is at its maximum, for it includes all that he possesses in his own right plus all that Congress can delegate" ${ }^{137}$ And did not the Supreme Court, in Dames \& Moore v Regan, ${ }^{138}$ adopt Justice Jackson's theory as a principle of adjudication in separation of powers cases?

Actually, this argument proves very little, as pointed out by my colleague E. Donald Elliott. Justice Jackson's approach, according to Elliott, "comes down to telling us that when the President acts with Congress behind him, he has more power than when he doesn't."139 The Jackson formulation, moreover, gives no clue about which congressional delegations should be sustained and which should not. Justice Jackson warns against striking down presidential actions under congressional authority, because to do so "usually means that the Federal Government as an undivided whole lacks power." ${ }^{40}$ That claim, however, is a terribly unpersuasive one, at least to the de-evolutionist. The federal government as an undivided whole possesses a good many powers, but not all of them can be exercised by the President, even with the concurrence of the Congress.

Justice Jackson's Steel Seizure opinion-although magnificent in many places-is thus at its weakest on the point for which it is cited most often. Certainly it provides no useful support for the Reagan claim that legislative powers, if delegated at all, must be

${ }^{136}$ See Chemerinsky, 103 Harv L Rev at $64-70$ (cited in note 17); Miller, 1986 S Ct Rev at 67-71 (cited in note 6).

${ }^{137}$ Youngstown Sheet \& Tube Co. $v$ Sawyer, 343 US 579, 635 (1952) (Jackson concurring).

${ }^{138} 453$ US 654 (1981).

${ }^{139}$ Elliott, 57 Geo Wash L Rev at 526 (cited in note 13).

${ }^{140} 343$ US at 636-37 (Jackson concurring). 
delegated to the President. Consequently, while the claim might perhaps have deserved better treatment than the brief and dismissive footnote that it received from the majority, the Justices were probably right to reject it. Still, whatever one might think of the Reagan effort to consolidate rulemaking power in the presidency, the Supreme Court's deference to congressional policy judgments in the face of separation of powers arguments ought to be troubling.

The Court, however, seemed unconcerned about other structural problems with the Commission. In fact, the Justices made the case look easy. Justice Blackmun's majority opinion explained that nothing was really different under the Sentencing Commission:

Prior to the passage of the Act, the Judicial Branch, as an aggregate, decided precisely the questions assigned to the Commission: what sentence is appropriate to what criminal conduct under what circumstances. It was the everyday business of judges, taken collectively, to evaluate and weigh the various aims of sentencing and to apply those aims to the individual cases that came before them. The Sentencing Commission does no more than this . ... ${ }^{141}$

No wonder, then, that the Court concluded that the legislation simply "consolidates" in the Commission "the power that had been exercised by the sentencing judge and the Parole Commission to decide what punishment an offender should suffer."142 This is a bit like saying that the Constitution simply consolidates in the federal government the power that had been exercised by the several states. Both statements mask radical restructurings of the allocation of authority by treating them as mere administrative conveniences.

In the past, the sentencing formula was so well understood that it was virtually a truism. The legislative branch decided on the range of punishment for offenses, the executive branch prosecuted, and the judicial branch imposed the punishment. ${ }^{143}$ Now the Sentencing Commission, an independent agency, decides on the range, and the judges must do as it tells them. The Mistretta majority explained that the traditional allocation had not actually

$141109 \mathrm{~S} \mathrm{Ct}$ at 666.

142 Id at 652 .

${ }^{143}$ For discussions of the accuracy or inaccuracy of this truism, see Shane, $30 \mathrm{Wm} \&$ Mary L Rev at 379-80 (cited in note 49) and Susan Low Bloch, The Early Role of The Attorney General in Our Constitutional Scheme: In the Beginning There Was Pragmatism, 1989 Duke L J 561. 
been changed, because the Commission, although independent, is "in" the judicial branch. ${ }^{144}$ That sleight of hand made the case trivial: the judicial branch sentenced before, the judicial branch sentences now. Nothing has changed!

As Justice Scalia pointed out in dissent, however, it isn't clear what it means to say that the Commission is "in" the judicial branch. ${ }^{145}$ The judges do not control it; the Chief Justice does not appoint its members; it is not answerable to any judicial body. In fact, the Commission is "in" the judicial branch only in a single sense-the statute says so. The rule consequently seems to be that an agency is where the Congress says it is; and the choice of the best place for the Commission is for the Congress to make.

The message of Mistretta echoed the Court's 7 to 1 decision a year earlier in Morrison v Olson, ${ }^{146}$ sustaining the constitutionality of the provisions of the Ethics in Government Act providing for appointment of an independent counsel to investigate allegations of wrongdoing in the executive branch. I have already written one lengthy appraisal of Morrison, ${ }^{147}$ and see no need to repeat myself here. Suffice it to say that Morrison, like Mistretta, reflected a vision of flexibility in the structural clauses of the Constitution. The logic of both cases is that the place to search for the constitutional validity of a new institutional form is not in the system of balanced and separated powers designed by the Founders, but rather in an assessment of the public policy rationale put forth on behalf of the institution under review. In that sense, the judicial function is not markedly different from the legislative.

Much has been said about the Supreme Court's 1935 decision Humphrey's Executor $v$ United States, ${ }^{148}$ and little need be added here. In that case, President Roosevelt sought to remove a commissioner of the Federal Trade Commission, notwithstanding a statutory restriction on the removal power. To the President's claim that the Commission exercised executive authority, which put it under the President's control, the Court responded with a casual "So what?" The Justices said that it was "plain" that nothing in the Constitution gave the President an "illimitable power of re-

$144109 \mathrm{~S} \mathrm{Ct}$ at $665-66$.

14 Id at 680-82 (Scalia dissenting).

146108 S Ct 2597 (1988).

117 See Carter, 102 Harv L Rev 105 (cited in note 6). I must apologize to the patient reader for the large number of citations in this article to my own work. Self-citation is, I fear, a hazard of first propounding and later discussing a theory with which no one else seems to agree. But this citation to my work is the last one.

14295 US 602 (1935). 
moval" over leaders of independent agencies. ${ }^{149}$ To recognize such a power, the Justices explained tersely, would threaten the Commission's "independence."

The trouble with all of this is that it places the shoe on the wrong foot. It should scarcely be surprising that the Constitution says nothing about the President's power to remove officers made independent by statute, because the Constitution says nothing about independent agencies at all. The Court had an answer for that, too: the congressional authority to establish independent agencies "cannot well be doubted."15i A legitimating opinion indeed-except that the Justices barely mentioned the Constitution's text and failed to cite a single scrap of its history. Humphrey's Executor, in short, may be rightly or wrongly decided, but the one thing that it is not is an example of the de-evolutionary tradition.

According to Clinton Rossiter, Humphrey's Executor represented one of the Supreme Court's "few spectacular victories over the President." 152 Possibly that was true in 1956, when Rossiter wrote; but if a victory occurs whenever the Justices reject a claim of presidential authority over independent entities, then it can fairly be said that the Supreme Court, in Morrison and Mistretta, has recently won two more.

Maybe victories are really what matter. The trouble with all of this, however, is that it does not take the separation of powers seriously. There is a sense in which this tendency is easy to understand. We live in an increasingly bureaucratic era, one in which an activist federal government regulates, and regulates a lot. It is quite natural in such a world that a legislature, impatient with the structure of government designed by the Founders, would stumble down the slippery slope toward delegating large chunks of its authority to quasi-independent agencies. ${ }^{153}$

Perhaps it was inevitable that the Court would yield to the congressional desire to deploy its authority without regard to the

149 Id at 629 .

130 Id at 630 .

131 Id at 629 .

${ }^{132}$ Clinton Rossiter, The American Presidency 57 (Harcourt, Brace \& World, 2d ed 1960). To put Rossiter's comment in perspective, I should add that he was also of the view that "[f]or most practical purposes, the President may act as if the Supreme Court did not exist," id at 56, a comment that I take to be less a recognition of raw power than an acknowledgment of what I have already pointed out, that the federal government operates in most of its functions without the need for judicial activity.

${ }^{153}$ Indeed, this is the entire point of what might be called New Deal constitutionalism. See Sunstein, 101 Harv L Rev at $422-25$ (cited in note 13). 
original design. But the development is hardly one to be celebrated. It might be a little strong to say, as Justice Scalia did in his Mistretta dissent, that the Court has permitted "the creation of a new branch altogether, a sort of junior-varsity Congress."154 But structure matters. The authors of the Constitution understood the risk of tyranny posed when the powers of government are not separated, and they designed a Constitution to put their political science into practice. Two centuries later, we are on the verge of forgetting their wisdom.

Probably the Justices did not intend to suggest that whatever the Congress says goes, but the lesson of Morrison and Mistretta certainly seems to be that we are moving dangerously close to that. Nothing in either opinion sets out a clear and reliable boundary between what the Court will permit and what it will not, which leaves the future rather uncertain. And neither opinion is truly deevolutionary in spirit, which leaves their legitimating force open to question.

Both Morrison and Mistretta are structural decisions, for both are about the locus of power. Neither involves an expansion of the authority of the federal government as a whole; no one denies that the power to investigate and prosecute executive malfeasance rests somewhere, nor that the political branches can set sentencing guidelines binding the judiciary. Each decision, however, involves what is in effect a reassignment of power from its original holder to a special individual or agency. In sustaining the reassignments in those cases, the Supreme Court has implicitly invited the Congress to continue to experiment with transfers of authority from a constitutionally assigned locus to a legislatively designated one. The invitation, however, is one that it might be constitutionally improper for the Congress to accept. Like Humphrey's Executor before them, neither Morrison nor Mistretta really offered much de-evolutionary analysis in support of their holdings. With the case for independent administrative government resting on so shaky a foundation, a wise Congress might still pause and ask itself whether a fourth branch of government might after all be a constitutional impropriety.

\section{ConcLusion}

De-evolutionary review is the key to legitimacy in adjudication under the structural clauses of the Political Constitution. But the 
Supreme Court, as it has shown in Mistretta and Morrison, is capable of occasionally forgetting the de-evolutionary lesson that it has in the past been at such pains to teach. On those occasions, politicians and bureaucrats who believe that Hamilton and Montesquieu were right, that unchecked power is bad in itself, and who understand the limitations on their own abilities to judge the extent of their own powers, should resist the temptation to stretch the limits of constitutional structure as far as the Justices are willing to let them go. They must announce, if only to each other, that the Court has done wrong, and that to do what the Court would allow, while perhaps not unconstitutional (given the lack of de-evolutionary analysis, the matter must be considered unsettled), is contrary to the document's spirit and therefore constitutionally improper. Thus, they should refuse the path of self-aggrandizement, and force the nation instead to follow the path of constitutionalism, trading the expediency of flexibility for the legitimacy of limitation.

"Self-restraint," says Professor Black, in closing his discussion of the legitimating function, "is always a paradox, a miracle." And he adds: "Behind all other perils lies the only one that really matters-the people may change their minds, and decide after all to abandon the idea of self-restraint through law." ${ }^{56}$ That is a peril in a dynamic and complex society, and the de-evolutionary tradition provides the means for its avoidance. When the Justices of the Supreme Court, in their rush to join a dialogue over wise and sensible policy, discard de-evolutionary interpretation, it is up to the political branches, unlikely though the idea might sound, to impose on themselves the restraint that the Court will not.

The Supreme Court's opinions in Morrison and Mistretta represent ringing endorsements of the ideal of independence in the administrative state. What is fascinating and sad about those opinions, however, is that they neither confront the strongest arguments for non-delegation nor provide analytically interesting counter-arguments. Consequently, neither Morrison nor Mistretta carries sufficient dialogic authority (as against interpretive authority) to alter any previously held conviction on the constitutional status of the agencies. To paraphrase Alexander Bickel, the decisions represent monologue, not conversation.

In this article, I have called upon the Congress and the President to keep alive the dialogue that Morrison and Mistretta

${ }^{15 s}$ Black, The People and the Court at 224 (cited in note 3).

156 Id. 
threaten to foreclose. Until the Court finally confronts in a convincing, coherent, and de-evolutionary way the constitutionality of the independent agencies, the political branches should not let matters drift further along merely because the Justices refuse to call a halt. My specific suggestion is that the political branches avoid accepting what might be termed the reverse binding effect of a legitimating decision; that is, the President and the Congress should not assume that simply because the Court has approved a particular institutional form and there are policy reasons in favor of its creation, there are no constitutional problems left to be solved.

In support of my appeal, I have developed a model of what I call constitutional improprieties, government actions that the courts are unwilling or unable to prevent but that violate the spirit of the Constitution nevertheless. Our traditional model of governance supposes that a politician asks herself only two questions: Will this help me get re-elected? Will the courts sustain it? My modest proposal is that she also ask a third: "Whatever the courts may say about it, is this measure in my judgment also consistent with the spirit of the Constitution that I am sworn to defend?"

I do not contend that politicians who ask themselves this question will reach the conclusion that administrative government resting on broad delegations of legislative and executive authority is constitutionally improper. My argument is simply that they should ask the question. I do suggest, however, that anyone concerned about limited constitutional government ought to feel at least a bit uncomfortable about the evidence that the Court has marshalled in support of its opinions purporting to legitimate various facets of the administrative state. And the more the discomfort that a reflective politician may feel, the less should be her willingness to assume that the Justices have solved for her the problem of constitutional propriety. 